\title{
Agricultural Greenhouse Gas Emissions in a Data-Scarce Region Using a Scenario-Based Modeling Approach: A Case Study in Southeastern USA
}

\author{
Mahnaz Afroz ${ }^{1}$, Runwei Li ${ }^{1}$, Gang Chen ${ }^{1}$ (D) and Aavudai Anandhi ${ }^{2, *}$ (]) \\ 1 Department of Civil and Environmental Engineering, FAMU-FSU College of Engineering, Tallahassee, \\ FL 32310, USA; mahnazdil1.afroz@famu.edu (M.A.); rl16h@my.fsu.edu (R.L.); gchen@eng.famu.fsu.edu (G.C.) \\ 2 Biological System Engineering Program, Florida A\&M University, Tallahassee, FL 32306, USA \\ * Correspondence: anandhi@famu.edu
}

Citation: Afroz, M.; Li, R.; Chen, G.; Anandhi, A. Agricultural Greenhouse Gas Emissions in a Data-Scarce Region Using a Scenario-Based Modeling Approach: A Case Study in Southeastern USA. Agronomy 2021, 11, 1323. https://doi.org/10.3390/ agronomy 11071323

Academic Editor: José L.S. Pereira

Received: 19 May 2021

Accepted: 24 June 2021

Published: 29 June 2021

Publisher's Note: MDPI stays neutral with regard to jurisdictional claims in published maps and institutional affiliations.

Copyright: (c) 2021 by the authors. Licensee MDPI, Basel, Switzerland. This article is an open access article distributed under the terms and conditions of the Creative Commons Attribution (CC BY) license (https:/ / creativecommons.org/licenses/by/ $4.0 /)$.

\begin{abstract}
Climate change may impact agricultural greenhouse gas emissions (GHGs) and yields under higher temperatures, higher atmospheric $\mathrm{CO}_{2}$ concentrations, and variable precipitations. This calls for adaptation strategies to optimize agricultural productions with minimal GHGs. This study aimed to identify these optimum agricultural managements in response to current and projected climatic scenarios for the Choctawhatchee Basin in Southeastern USA, an experimentally unexplored data-scarce region lacking validation data. This scenario-based modeling study analyzed a total of 1344 scenarios consisting of four major crops, eight managements (varying tillage, manuring, and residue), and forty climatic combinations under current as wells as two representative concentration pathways with process-based Denitrification and Decomposition (DNDC) model. The results indicated that the region's GHGs and yields were most affected by higher temperatures $\left(\geq+3{ }^{\circ} \mathrm{C}\right)$ and extreme precipitation changes $(\geq \pm 40 \%)$, while high atmospheric $\mathrm{CO}_{2}$ concentrations exerted positive fertilization effects. The manure-related and higher residue incorporation scenarios were found to be better options in varying climates with minimal present global warming potentials (GWP) of $0.23 \mathrm{k}$ to $-29.1 \mathrm{k}$ MT equivalent $\mathrm{CO}_{2}$. As such, the study presented climate change impacts and potential mitigation options in the study region while presenting a framework to design GHG mitigation in similar data-scarce regions.
\end{abstract}

Keywords: greenhouse gas; climate change; alternative managements; scenario development

\section{Introduction}

\subsection{Background}

1.1.1. Agriculture, Climate Change, and Associated Greenhouse Gas Emissions

Agriculture and related land-use changes are some of the major sources of climate change responsible for about $25 \%$ of total anthropogenic $\mathrm{CO}_{2}, 50 \%$ of $\mathrm{CH}_{4}$, and $70 \%$ of $\mathrm{N}_{2} \mathrm{O}$ emissions [1-5]. A significant portion of the agriculture-associated emissions is directly related to field-level agricultural management practices. For example, in wheat cultivation systems during aerobic upland cropping, $48 \%$ of total $\mathrm{N}_{2} \mathrm{O}$ emission was attributed to the production of used amount of fertilizer $(192 \mathrm{kgN} / \mathrm{ha})$, and the other $52 \%$ was claimed to be associated with the nitrification-denitrification in the agricultural soil [6].

Moreover, during the past 50 years, agricultural production increased 2.5 to 3 times, whereas the cultivated area increased by only $12 \%$ [7]. Despite this increase, approximately one billion people are considered undernourished [8]. Additionally, the demands for food are estimated to increase by $35 \%$ by 2030 [9] and are further estimated to increase by over $50 \%$ by 2050 compared with that of 2015 [10].

To feed the ever-growing population, both the agricultural activities and the associated emissions increased significantly over the past few decades. This agricultural emission has the potential to increase even more in future climatic conditions with increased temperature, 
elevated $\mathrm{CO}_{2}$ concentration, fluctuated precipitation, and frequent extreme events [4]. From 1850 to 2010, the emissions of $\mathrm{CO}_{2}, \mathrm{~N}_{2} \mathrm{O}$, and $\mathrm{CH}_{4}$ were elevated by $42 \%, 15 \%$, and $125 \%$, respectively. They are predicted to increase even more (by about $200 \%$ ) under the highest assumed radiative forcing by the end of the 21st century [11,12]. These projected changes of climatic components are likely to escalate overall agricultural GHGs, especially $\mathrm{N}_{2} \mathrm{O}$, and decreased carbon sequestration in the soil [13-15].

It was claimed that increased temperature and fluctuated precipitation induced by climate change might decrease the crop yield due to reduced water availability and increased temperature $[16,17]$. On the other hand, some studies argued that increased yield might increase in response to the increased water availability, temperature, and atmospheric $\mathrm{CO}_{2}$, etc. [18-20]. Although various studies contradicted the impact of increased temperature on crop yield, there was consensus that the doubled atmospheric concentration of $\mathrm{CO}_{2}$ had the potential to increase crop yield by approximately $30 \%$. However, the pattern of the changes cannot be correctly assumed without considering the complex interactions of the overall agroecosystem with the climate variability at local or regional scales [4].

\subsubsection{GHG Mitigation Strategies with Management Options}

To combat climate change, adaptation within the agricultural system can be achieved either by introducing innovative management practices to minimize the vulnerability of the existing system or by reconstructing the whole system to take advantage of the changing climate $[21,22]$. As such, the identification of the management practices with the potentials to minimize the global warming potential (GWP) while maintaining optimum crop yield, soil fertility, and economic return is the most efficient way of adaptation to the changing climate.

Different agricultural management practices have varying impacts on carbon sequestration, GHG emissions, yield response, and soil fertility, etc. [23]. The explored management practices in this paper include residue management, conservation tillage (from conventional tillage (CT) to no-tillage (NT)), and nutrient management (optimized use of mineral fertilizers and manures). Tillage conservation and higher residue incorporation are frequently explored to sequester $C$ and reduce the net GWP [24-26]. NT was also found to be a beneficial means of increasing $C$ sequestration in both present and future climatic scenarios in various studies $[3,20,27]$, but it may also impact $\mathrm{N}_{2} \mathrm{O}$ emission and crop yield in both positive or negative ways depending on the overall soil-climatic-crop interactions [28,29].

Previously, factors such as cropping practices, soil management, and rainfall were considered as more sensitive variables than fertilizer types in terms of $\mathrm{N}_{2} \mathrm{O}$ emission minimization. However, some studies showed a significant reduction in their emissions by choosing effective fertilizer types based on soil and environmental conditions [30,31]. Additionally, optimal fertilizer dose selection is a significant decision to obtain the optimum yield returns with minimal negative impacts on climate and soil fertility [6]. The combination of mineral fertilizer, manure, and higher residues showed significant improvement in C stock in some regions, even though the soil organic carbon (SOC) stock can largely vary with crop types [32]. Besides, the optimized use of manure along with mineral fertilizers may be a potential way for long-term conservation of soil C-sequestration and yield maintenance [33].

\subsubsection{Model Overview and Emission Prediction in a Data-Scarce Region}

Emission prediction of agroecosystems can be evaluated by emission factors, processbased models, or direct observations, which are listed in the order of increased confidence in the prediction [34,35]. As direct observations are only practical for small-scale site studies, feasible options for the regional level emission prediction are dynamic process-based models and the IPCC emission factor. Comparing these two methods, the dynamic processbased models are expected to introduce significantly more confidence by considering 
spatial and temporal variations in soil, climate, and management practices for regionalscale emission predictions [35].

In this study, the Denitrification and Decomposition (DNDC) model was chosen as the tool to identify the key decision parameters for planning and designing the emission mitigation strategies for both the present and the future climatic scenarios. The DNDC model [36-38] is a process-based biogeochemical model, which is capable of predicting crop yield, soil environmental processes, $\mathrm{C}$ sequestration, and emissions of $\mathrm{C}$ and $\mathrm{N}$ gases in agroecosystems. Though originally developed for the prediction of $\mathrm{N}_{2} \mathrm{O}$ from cropland, this model was enriched and modified with time for simulating the overall carbon (C) and nitrogen $(\mathrm{N})$ biogeochemistry of other ecosystems such as rice paddy, forests, wetlands, grazed pastures, and so on [23]. Thus far, the model was thoroughly calibrated and validated with many measured datasets of trace gas emission and several other ecological indicators [23,39]. The model default parameters (based on U.S. average) and algorithm regarding soil hydrological parameters, soil library, and phenology of the crops defined in the crop library were also able to predict soil biogeochemistry with acceptable accuracy [40].

Modeling is one of the globally accepted methods for the prediction of soil emissions at the regional scale. However, most of the modeling studies are validated with site-scale emission data for attaining better confidence in the result. In the studied region, the field emission measurements were not available at all, for which reason it was called a datascarce region in terms of validation purposes. To deal with the challenge of planning GHG mitigation for such a region, the strength of satisfactory prediction of the DNDC model was used [39,41]. Here, the best available data on soil, environmental, and management parameters were used along with the default DNDC parameters to predict GHGs and crop yields under different management and climatic scenarios. The adaptation strategy on this data-scarce region was designed by validating the model with another parameter (crop yield), for which county-level data were available. This approach was claimed as a way to validate the model in a few of the previous studies [20,29,35,42]. This study explicitly tried to present this way through this case study.

\subsection{Objective and Study Overview}

This study aimed to identify the best agricultural management as well as GHG mitigation options in response to current and plausible climate change scenarios at the Choctawhatchee Basin by generating model estimates of GHGs along with yields. However, the aim was achieved by implementing the following objectives:

- Assessing the impacts of varying management practices in the present climate;

- Assessing the impacts of varying precipitations and temperature plus $\mathrm{CO}_{2}$ concentrations on the baseline management practice;

- Assessing the impacts of varying management practices in the varying temperature plus $\mathrm{CO}_{2}$ concentration and the baseline precipitation.

Here, each of the objectives was explored in terms of four major crops and three decision parameters (yield, $\mathrm{N}_{2} \mathrm{O}$, and GWP). The varying climate parameters (precipitation and temperature plus $\mathrm{CO}_{2}$ ) were associated with plausible future climate change. However, being conducted on a data-scarce region, this research also developed a framework for designing greenhouse gas mitigation strategies for data-scarce instances. Moreover, the regional simulation conducted on 147 HUC 12 sub-watershed grids provided an overview of the GHG hotspots and potential management options for the area as an added outcome.

As for the overview of the following sections, first, the study area, data, and methodologies (scenario generation, model validation, model runs, etc.) are described in Section 2. Then, the relevant results and discussion regarding each of the three research objectives are discussed in Sections 3 and 4. Finally, the study is concluded in Section 5 with key findings, limitations, and recommendations. 


\section{Materials and Methods}

\subsection{Study Area}

The study area of this research is the Choctawhatchee Basin (hydrologic unit code 6 (HUC 6): 031402), which has an area of $12,051 \mathrm{~km}^{2}$ and is located covering two states (Alabama and Florida) of the Southeastern USA (Figure 1a). The basins around the Choctawhatchee River are usually characterized by the topography of gentle to moderately rolling hills in the upper northern portion with crests about 600 feet above sea level. Additionally, the lands, excluding some of the flood plains, are well drained and conducive to the growth of row crops and for use in other agricultural pursuits [43].

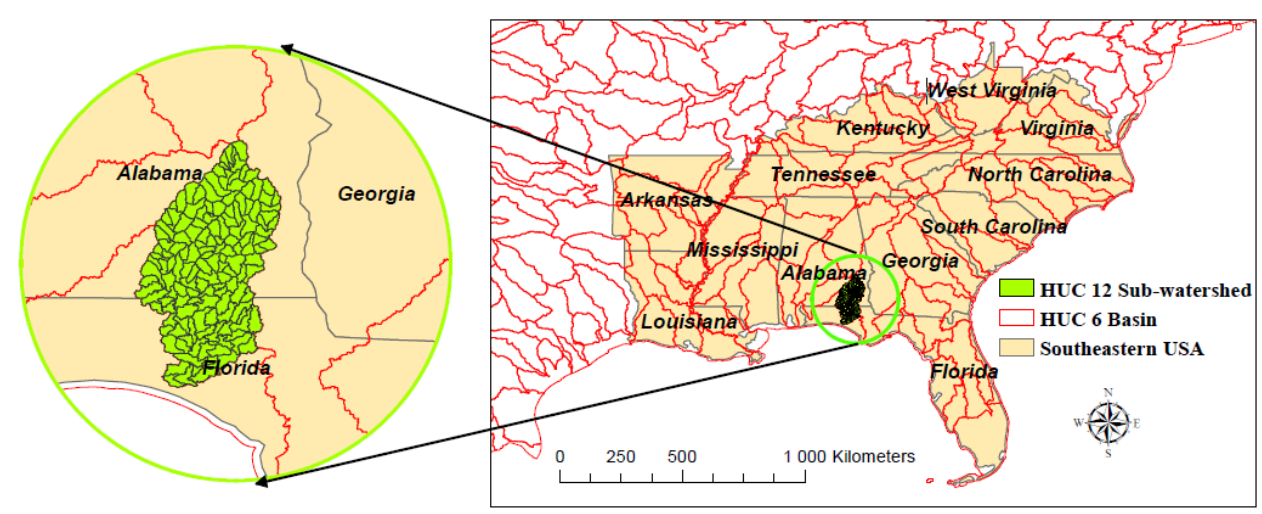

(a)

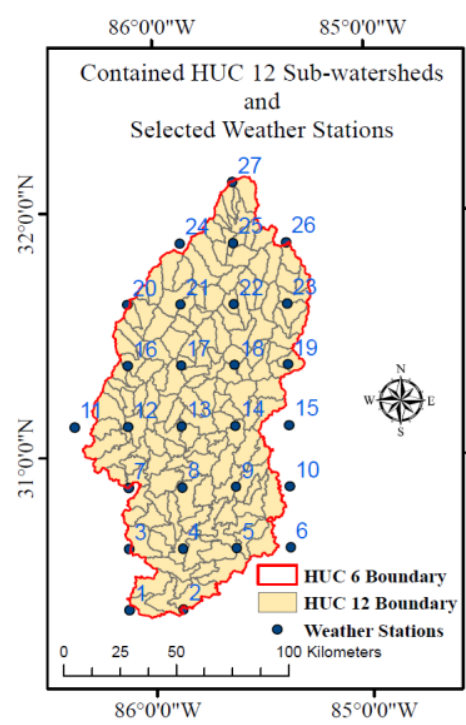

(b)

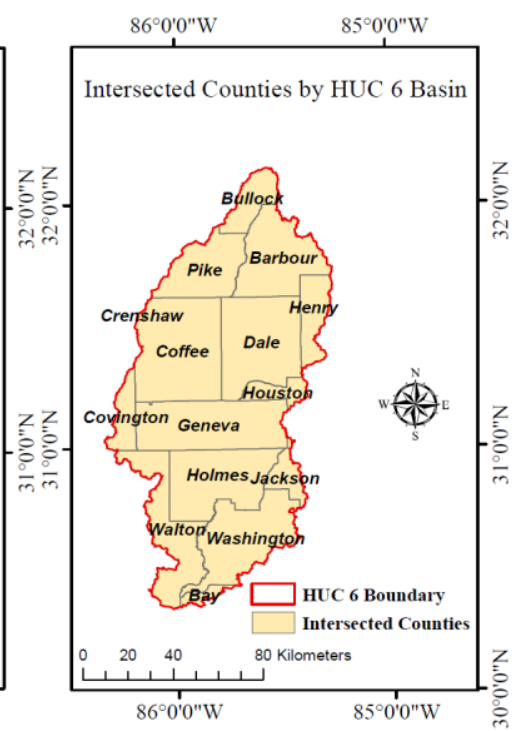

(c)

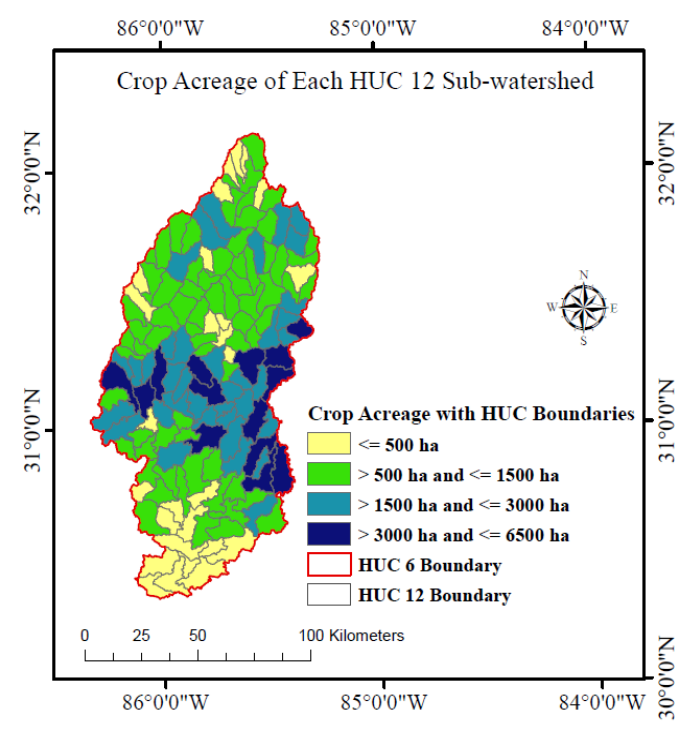

(d)

Figure 1. (a) The locator map of the Choctawhatchee Basin, (b) the contained smaller HUC 12 sub-watersheds with the selected weather stations, (c) the intersected counties, and (d) the calculated crop acreage.

However, the specific study basin intersects 15 counties in total, where ten of them are from Alabama and five from Florida. As per the calculation on the crop data layer (CDL) of 2016, the mid-region of the area has the highest agricultural acreage [44] (Figure 1d). The agricultural landscape comprises an upland cropping system with sandy loam (44.63\%) and loamy sand (39.55\%) as major soils, where the four major crops are cotton, peanut, corn, and soybean. The calculated average annual precipitation for the Choctawhatchee Basin (over 39 years and with the selected 27 stations) (Figure 1b) was $152.7 \mathrm{~cm}$ with DAYMET grid data $\left(0.25^{\circ} \times 0.25^{\circ}\right)$, and the annual average temperature for the timeline was about 
$19^{\circ} \mathrm{C}$. The area located in the southeastern United States is a warm and moist region [45]. Climate change prediction and adaptation strategies based on the local region and the cropping system can be more reliable, as the responses of management practices are mostly region and cropping system-specific [4,21,30]. As such, the climate, soil, and agricultural systems of the target region were analyzed, and potential options were presented for further analysis in this study.

\subsection{Summary of the Process Flow}

To conduct the simulation over the whole study area, the DNDC model can be run both in the regional mode as well as the site mode in batch. The regional mode has limitations associated with model parameters as many of them are determined internally (e.g., atmospheric $\mathrm{NH}_{3}$ content and soil hydraulic conductivity, etc.), which cannot be accessed and modified. But the site mode is claimed to predict the emission level with better confidence, as more local parameters can be inputted [42]. Thus, the site mode with batch running approach was used in this study, which enabled the model to predict the outputs with improved confidence and decreased run time by overcoming several limitations of the regional mode. The overall modeling methodology of this study was carried out by dividing the work into various steps and levels, as summarized in Figure 2.

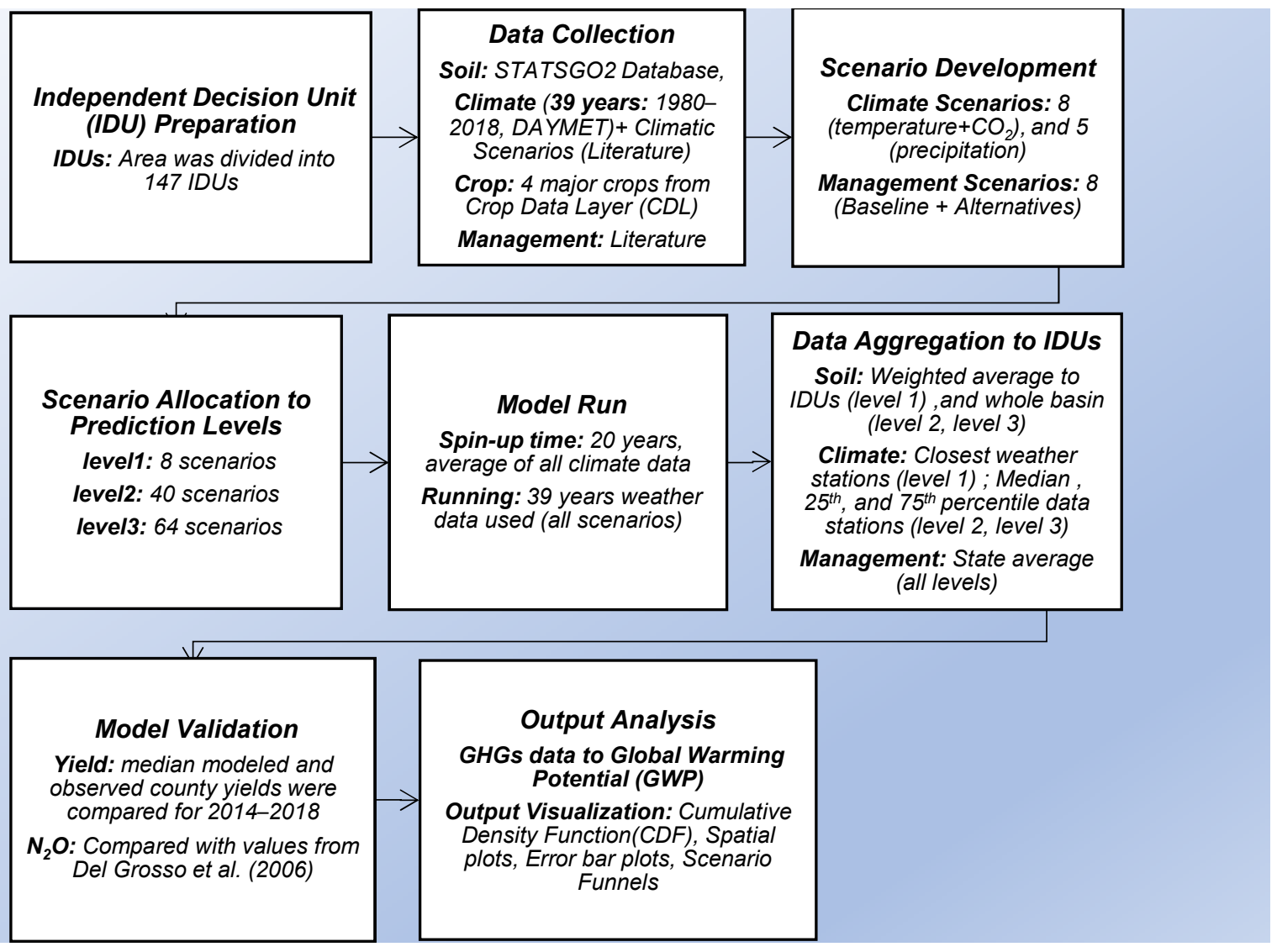

Figure 2. Process flow diagram for the overall summarized workflow of the methodology.

By the data analysis, the prediction of decision parameters (i.e., grain yields and GHGs) were obtained. And, the tasks regarding each of the objectives were tagged as different levels. Assessing varying managements in the present climatic conditions was tagged as level 1. Assessing the impacts of varying precipitation and temperature plus $\mathrm{CO}_{2}$ concentration on the baseline management practice (second objective) was tagged as level 2. Finally, assessing the impacts of varying management practices in the varying 
temperature plus $\mathrm{CO}_{2}$ concentration and the baseline precipitation (third objective) was named level 3 (Figure 2).

\subsection{Independent Decision Unit (IDU) Preparation}

In this study, the larger Choctawhatchee Basin (HUC 6) was subdivided into smaller sub-watersheds (HUC 12) where climate, soil properties, and cropping management properties were assumed to be the same during the model simulation. The polygonal subwatersheds were referred to as IDUs $[29,46,47]$. The area of the used IDUs varied from 2840 ha $\left(28.4 \mathrm{~km}^{2}\right)$ to $15,772 \mathrm{ha}\left(157.72 \mathrm{~km}^{2}\right)$. As the soil properties did not vary significantly in this basin-with only two major soil types (i.e., sandy loam and loamy sand) covering the upland cropping system - this level of IDUs was assumed to capture the spatial soil distribution. Even though more confidence can be achieved with smaller grid cells, it also increases the model run time and the complexity of data collection and data availability.

\subsection{Data Collection}

The input data required for the DNDC model were classified into four broad groups: soil data, weather data, phenology data, and management data. Data collection was one of the most crucial parts of the overall simulation process, as the accuracy of the simulation is largely dependent on the quality of data. The soil data for Alabama and Florida were derived from U.S. General Soil Map by state (STATSGO2), as the study area was located covering the states [48]. Then, the derived spatial soil data were viewed and extracted with Soil Data Viewer Version 6.2, an ArcGIS add-in created by the United States Department of Agriculture [49]. The STATSGO2 map was divided into polygon cells, which contained similar soil properties and were identified by a map unit key ("MUKEY"). The soil properties extracted with soil data viewer were surface texture, organic matter (\%), clay (\%), $\mathrm{pH}$, bulk density $\left(\mathrm{gm} / \mathrm{cm}^{3}\right)$, saturated hydraulic conductivity (um/s), and slope (\%).

The background atmospheric $\mathrm{NH}_{3}$ concentration was incorporated from a study by averaging fall, spring, summer, and winter $\mathrm{NH}_{3}$ concentrations of the southeastern USA [50]. The atmospheric net $\mathrm{N}$ deposition data were collected from the three closest stations (SUM256, GA253, and SND152) to the study area for 18 years (2000-2017). The median value of all the observations was used as the model input to represent the net atmospheric deposition of the present timeline [51].

The daily weather data used for the present (base timeline-1980-2018) in this study were extracted from DAYMET climate data simulated over $1 \mathrm{~km}$ spatial grids [52]. The data sets were widely used for various bio-geochemical simulation studies over North America [53]. For this study, the data were extracted over $25 \mathrm{~km}$ grids and 27 stations.

The plausible future climatic data chosen for this study were selected mainly from two studies on the southeastern USA and Florida's climate scenario analysis [54,55]. By both meta-analysis and GCM (global circulation model) data analysis on the southeastern USA, Anandhi and Bentley (2018) represented the temperature change of $-3{ }^{\circ} \mathrm{C}$ to $6{ }^{\circ} \mathrm{C}$ by 2099 . They found the changes in precipitation in SEUSA to be $-30 \%$ to $+35 \%$ (meta-analysis), 0\% (GCM data analysis: median), and $-40 \%$ to $40 \%$ (GCM data analysis: 25 th and 75 th percentiles) by 2099 from the historical baseline (1950-2005) [55]. Similar claims were found in Anandhi et al. (2018). Another significant input, atmospheric $\mathrm{CO}_{2}$ concentration, was adapted from mean projected $\mathrm{CO}_{2}$ concentration scenarios generated from two of the representative concentration pathways (RCP) (Pachauri et al., 2015) and literature reviews $[11,56]$. There are four RCPs (RCP 2.6, RCP 4.5, RCP 6, and RCP 8.5) with four levels of socioeconomic assumptions of radiative forcing for the ongoing century, which predict the climate change response with four predicted levels of increasing GHG concentrations $[11,56,57]$. Tabular details of climate are in the Supplementary File (Tables S1-S3).

For simulation purposes, four major crops were selected from the crop data layer (CDL) of 2016 [44]. Most of the phenology-related inputs for the selected crops were derived from the DNDC crop library, which was mainly set with U.S. average values [23]. 
Few parameters such as nitrogen fixation rate of peanut and maximum yield were modified according to yield and crop properties of the region [58].

The baseline management data were generated assuming the possible existing conditions for the whole basin. The amounts of fertilizers considered for the scenarios were taken from the typically used amounts for corn, peanut, soybean, and cotton in the state: $200 \mathrm{kgN} / \mathrm{ha} / \mathrm{y}, 0 \mathrm{~kg} \mathrm{~N} / \mathrm{ha} / \mathrm{y}, 0 \mathrm{kgN} / \mathrm{ha} / \mathrm{y}$, and $84 \mathrm{kgN} / \mathrm{ha} / \mathrm{y}$, respectively $[59,60]$. The planting and the harvesting dates were also incorporated at the state level [61]. The tillage conditions incorporated for the baseline were divided into two parts: $20 \mathrm{~cm}$ deep plowing with moldboard during or before planting, and $10 \mathrm{~cm}$ deep plowing with disk or chisel after harvesting [46,62-64]. The irrigated percentages of crop acreages of the study area varied between $1 \%$ to $23 \%$, which was assumed to be dominated by a non-irrigated system $[44,65]$. Therefore, the analysis was conducted assuming non-irrigated cases with the model irrigation index setting to 0 .

\subsection{Climate and Management Scenario Development}

The climate-related scenarios were developed by varying ranges of temperature, precipitation, and atmospheric $\mathrm{CO}_{2}$ concentration with change factors [46,66]. The managementrelated scenarios were generated by varying management components (nutrients, residue, and tillage).

Considering baseline (1980-2018) and target future projection periods (around 2100) of this study, eight-step temperature changes $\left(-3{ }^{\circ} \mathrm{C}\right.$ to $\left.+6^{\circ} \mathrm{C}\right)$ with $1.5^{\circ} \mathrm{C}$ increments were considered. Cooling scenarios $\left(-3^{\circ} \mathrm{C}\right.$ to $\left.-1^{\circ} \mathrm{C}\right)$ were included in the study even though the temperature was most likely to increase in the considered timeline of this study [54,55]. The cooling scenarios showed the impacts of reduced temperature, which resulted in a wider range of observations. For atmospheric $\mathrm{CO}_{2}$ concentrations, three values were used: one baseline (370 ppm, a middle value for base time range), RCP 4.5 (538 ppm), and RCP 8.5 (936 ppm) (Supplementary File, Tables S1-S3). Since no study was found on the atmospheric $\mathrm{CO}_{2}$ concentration of SEUSA, the global assumption was used.

Temperature and $\mathrm{CO}_{2}$ changes were combined to generate scenarios by the pattern that the higher temperature-radiation scenarios were more likely to be associated with higher projected $\mathrm{CO}_{2}$ levels and vice versa, as indicated in RCPs [11,67]. Thus, to explore the projected future climate variability in terms of temperature and $\mathrm{CO}_{2}$ concentration, the two lower temperature $\left(1.5^{\circ} \mathrm{C}\right.$ and $\left.3^{\circ} \mathrm{C}\right)$ scenarios were combined with $\mathrm{RCP} 4.5$ mean $\mathrm{CO}_{2}$ concentration of $538 \mathrm{ppm}$, and three higher temperature $\left(3^{\circ} \mathrm{C}, 4.5^{\circ} \mathrm{C}\right.$, and $\left.6{ }^{\circ} \mathrm{C}\right)$ scenarios were combined with RCP 8.5 mean $\mathrm{CO}_{2}$ concentration of 936 ppm [11]. Additionally, the two cooling scenarios $\left(-3{ }^{\circ} \mathrm{C}\right.$ and $\left.-1.5^{\circ} \mathrm{C}\right)$ were combined with the present $\mathrm{CO}_{2}$ concentration (370 ppm). Overall, the total number of temperature- $\mathrm{CO}_{2}$ combinations was eight: one base and seven projected. The projected mean global increases in temperature as well as $\mathrm{CO}_{2}$ concentrations under RCP 4.5 and RCP 8.5 were seen to be $1.1-2.6{ }^{\circ} \mathrm{C}$ with 538 ppm and $2.6-4.8{ }^{\circ} \mathrm{C}$ with 936 ppm, respectively, which justifies the combination further [11].

Further, to introduce the precipitation uncertainty bounds in the scenarios, five precipitation change scenarios with $20 \%$ increments were generated in the range of $+40 \%$ to $-40 \%$. With the prior eight scenarios, the precipitation bounds made the total number of scenarios 40: (8 temperature- $\mathrm{CO}_{2}$ combinations) $\times(5$ precipitation scenarios: $-40 \%,-20 \%$, $0 \%,+20 \%$, and $+40 \%$ ). This value was mainly taken from the 25 th and the 75 th percentile of GCM data analysis from a study, which was also consistent with other studies [54,55]. All the relevant data of climate scenario generation are tabulated in Tables S1-S3.

In this study, eight alternative management scenarios were generated by varying three management components: nitrogen $(\mathrm{N})$ input rate (fertilizer or manure), residue incorporation rate, and tillage type from the examples in the previous literature (Table S4). Methodologies regarding management scenarios were well documented in a regional SOC study in China, which can be taken as an example [32] along with some other important 
papers $[28,29,36,37]$. However, the development of climatic and management scenarios as well as their allocation to multiple levels are summarized in Figure 3a,b.

\subsection{Scenarios and Prediction Levels}

The generated scenarios were allocated to three prediction levels, where level 1, level 2, and level 3 consisted of the relevant scenarios to implement the first, the second, and the third objective of this study. The details of scenario allocations from the objective and the axis plus matrix perspectives are depicted in Figure $3 \mathrm{~b}$.

At level 1, the 8 scenarios ( 8 managements $\times 1$ baseline climate) presented how the alternative managements would impact the present climate. At level 2, the 40 scenarios ( 1 baseline management $\times 40$ climate scenarios) showed what the impact of changes in the three major climate factors (temperature, precipitation, and $\mathrm{CO}_{2}$ ) would be if the base management was retained in changed climate. Finally, level 3 depicted how the alternative managements would impact under the changes of two major climate factors (temperature plus $\mathrm{CO}_{2}$ ), which was presented by 64 scenarios ( 8 managements $\times 8$ temperature plus $\mathrm{CO}_{2}$ combinations). Here, level 1 was representative of present climate (1980-2018), while level 2 and level 3 represented plausible climate change scenarios toward 2100. Each scenario was assessed for three decision parameters (grain yield, $\mathrm{N}_{2} \mathrm{O}$, and GWP), whose values were determined for four major crops. Level 1, level 2, and level 3 analysis yielded 96 ( 3 outputs $\times 4$ major crops $\times 8$ scenarios), 480 ( 3 outputs $\times 4$ major crops $\times 40$ scenarios), and 768 ( 3 outputs $\times 4$ major crops $\times 64$ scenarios) results, respectively. The conclusion of this study was drawn from 1344 output results generated from all levels and scenarios.

\section{Scenarios: Management axis}

(Residue, Manure, Fertilizer, Tillage )

\begin{tabular}{|c|l|}
\hline $\mathbf{m} 1$ & Baseline \\
\hline m2 & $80 \%$ Residue Incorporation \\
\hline m3 & $500 \mathrm{kgC} /$ ha Manure Addition \\
\hline m4 & $1000 \mathrm{kgC} /$ ha Manure Addition \\
\hline m5 & $2000 \mathrm{kgC} /$ ha Manure Addition \\
\hline m6 & $50 \%$ Fertilizer \& Manure Addition \\
\hline m7 & No-till with $15 \%$ Residue \\
\hline m8 & No-till with $50 \%$ Residue \\
\hline
\end{tabular}

8 Scenarios: Climate axis-1

(Temperature $+\mathrm{CO}_{2}$ Concentration)

\begin{tabular}{|c|c|c|c|c|c|c|c|c|}
\hline Climate axis-1 & $\mathbf{c 1}$ & $\mathbf{c 2}$ & $\mathbf{c 3}$ & $\mathbf{c 4}$ & $\mathbf{c 5}$ & $\mathbf{c 6}$ & $\mathbf{c 7}$ & $\mathbf{c 8}$ \\
\hline Temperature $\left({ }^{\circ} \mathrm{C}\right)$ & -3 & -1.5 & 0 & +1.5 & +3 & +3 & +4.5 & +6 \\
\hline $\mathrm{CO}_{2}$ Conc. $(\mathrm{ppm})$ & 370 & 370 & 370 & 538 & 538 & 936 & 936 & 936 \\
\hline
\end{tabular}

Climate axis-1 (temperature+ $\mathrm{CO}_{2}$ )

\begin{tabular}{|c|c|}
\hline Climate axis-2 & precipitation \\
\hline $\mathbf{p 2}+$ & $+40 \%$ Precipitation \\
\hline $\mathbf{p 1}+$ & $+20 \%$ Precipitation \\
\hline p0 & Baseline \\
\hline p1- & $-20 \%$ Precipitation \\
\hline p2- & $-40 \%$ Precipitation \\
\hline
\end{tabular}

5 Scenarios: Climate axis-2

(Precipitation (pcp.))

(a)

Figure 3. Cont. 


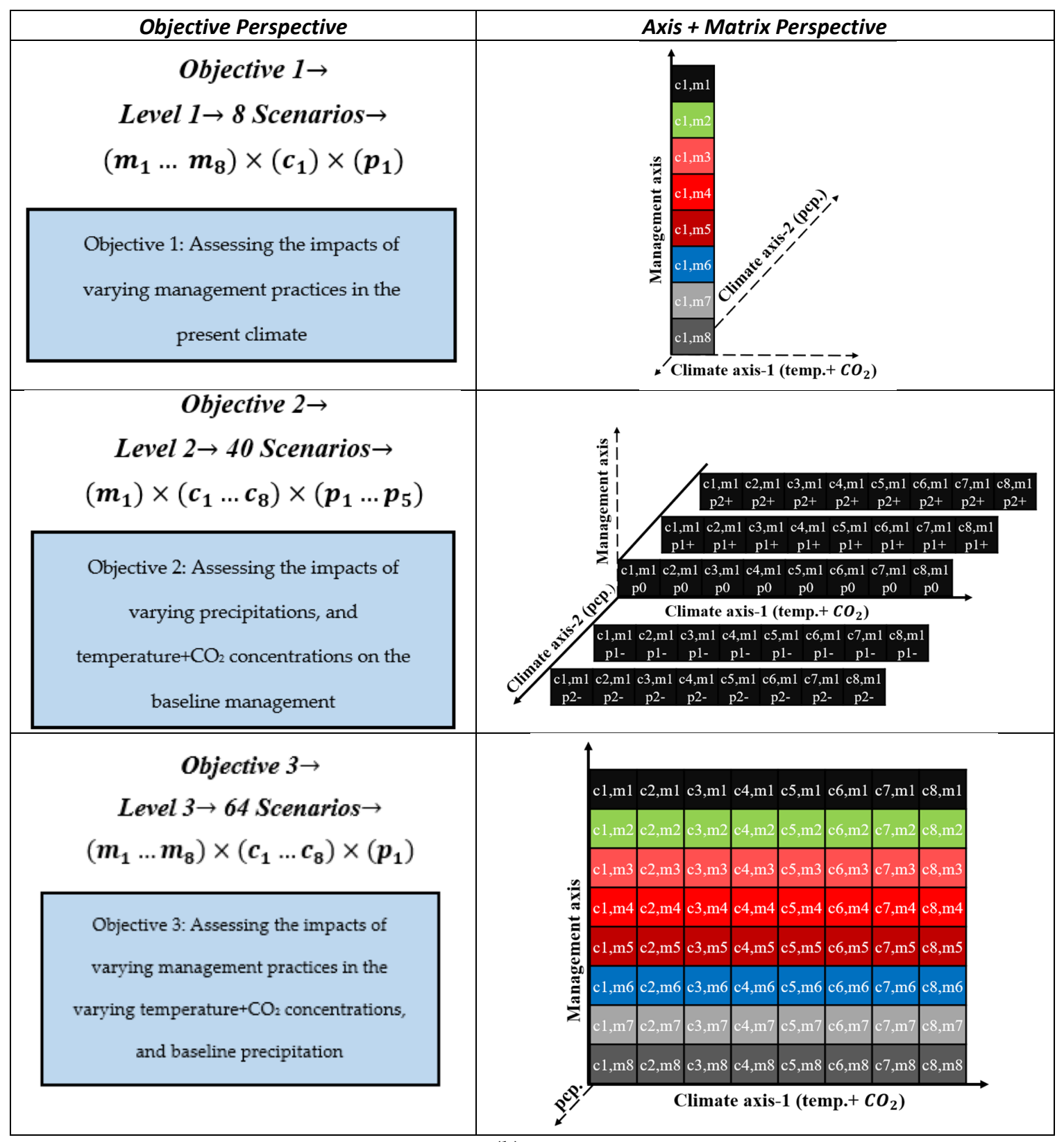

(b)

Figure 3. (a) The climatic and the management scenarios developed in the study (color codes assigned to managements scenarios enabled visual separation) and (b) the allocation of the developed scenarios to multiple levels as per the relevant objectives of three levels of the study (dotted axis: constant parameter, solid axis: varied parameter).

The precipitation scenarios in this study were generated based on Anandhi and Bently (2018), where the median precipitation change in the southeastern USA was found to be about $0 \%$, and the 25 th-75th percentile range was $-40 \%$ to $40 \%$ by 2099 from the baseline [55]. Though five precipitation scenarios within $-40 \%$ to $40 \%$ range were included in level 2 analysis to show the effects of all three climate factors, they were not included in level 3 analysis. Since precipitation change was a highly uncertain parameter (median $0 \%$ ), the objective of level 3 as well as the study was to show the impacts of varied managements under a snippet of climate change (varied temperature plus $\mathrm{CO}_{2}$, baseline precipitation) with fewer scenarios. The idea about the extent of changes was already gained in level 2, and inclusion of it in level 3 would have caused $80 \%$ increase in computational time (320 scenarios instead of 64). 
Unlike most of the previous studies, the climate change scenarios due to simultaneous and more practical variations of major climate components in the study region were used in the latter two levels of this study $[66,68]$. Previous studies generated the scenarios by varying only a single weather component (e.g., temperature increment or precipitation change) or management components (e.g., fertilizer, tillage, residue, and manure) at a time, where the overall climate change by compound change in major climate components was not considered $[28,29,36,63]$. However, level 1 presented the individual impact of each management, whereas levels 2 and 3 mainly highlighted compound impacts by partially representing the individual impact of climate components.

\subsection{Data Aggregation to IDUs}

The collected data for the model inputs were aggregated to each IDU (i.e., HUC 12 sub-watershed grids) for the model runs. All types of inputs were logically assigned to the IDUs for full-scale analysis at level 1.

For the required soil properties, the weighted average (W.A.) was calculated for each IDU. The Choctawhatchee Basin is dominated by two broad classes of soil texture class: sandy loam (44.63\%) and loamy sand (39.55\%). The percentage of organic soil (muck) is $8.49 \%$, however, the muck was avoided during the W.A. calculation, which was found to be associated with wetlands having zero water table and no intersection with agriculture class in the CDL [44]. This approach helped avoid the overestimation of modeled GHGs (mainly $\mathrm{N}_{2} \mathrm{O}$ ), as the high SOC of muck can exponentially increase the model $\mathrm{N}_{2} \mathrm{O}$ predictions [37]. The dominant soil organic matter (SOM) in the study region was found to be $0.75 \%$ and was converted to soil organic carbon (SOC) using a factor of $0.58[69,70]$.

During weather data input, each of the 27 stations (Figure 1a) was assigned to the IDUs based on the closest distance. At level 1, temperature and precipitation data of all 39 years (1980-2018) and 27 stations were assigned to 147 IDUs (level 1). Next, the crop acreages of the four major crops were calculated from the CDL of 2016 for each IDU at level 1. For the management data, the state average timeline and the most common management for all the IDUs (level 1) and the whole basin (levels 2-3) were used.

During level 2 and level 3, three of the weather stations were chosen, which had the closest cumulative monthly precipitation values to the median, the 25th, and the 75 th percentiles precipitation values among the 27 stations for 39 years. Because the monthly temperature variation among the 27 stations was insignificant, the stations that captured the regional variability were chosen based on the precipitation only. The data of these 3 stations were modified by adding temperature changes and multiplying precipitation percentages, which were used to combine with the median soil properties of the region to form future scenarios at a reduced computational expense.

\subsection{Model Run and Validation}

DNDC requires an initial 10-20 years of spin-up run to achieve a soil steady state, which is sensitive to both weather and management $[29,35,42,71,72]$. The crop residue decomposition - which is responsible for altering the SOC equilibrium-takes approximately 20 years to establish a new equilibrium [34,35]. As such, the steady state was achieved by repeating the model run for 20 years using the average of present climate data (Figure S1). The SOC reached the equilibrium when SOC change in a particular year was less than 5\% from the previous five years [35].

Thus, the total simulation period for the run was 59 years, including the 20 spin-up years. The initial 20 years of the spin-up run were conducted with the average weather data of 39 years of all the stations. The later 39 years of the run were conducted with present timeline climate data (1980-2018) of 27 stations (level 1) or modified data of 3 selected stations (level 2-3) to capture inter-annual and spatial variabilities over the area [35,42]. The equilibrium in $\mathrm{N}_{2} \mathrm{O}$ was claimed to be achieved in less time compared to the SOC equilibrium time (5-10 years). 
Model validation: the region simulated in this study was a data-scarce region where no field measurements of $\mathrm{N}_{2} \mathrm{O}$ or other GHGs were available. As such, extensive calibration and validation with daily measurements of GHGs were not conducted. A two-step course validation with two model outputs was conducted to show that the model predictions of yield and $\mathrm{N}_{2} \mathrm{O}$ were in reasonable ranges (Figure 4 ).

First, the median yields of each major crop of the intersected counties and the model predictions of them for the same five years (2014-2018) were compared. This level of course validation with regional crop yields was mentioned as a way of increasing the confidence in model estimation and was used in a few of the previous studies with field data scarcity [20,29,35,42]. For example, Thomson et al. (2006) similarly validated the model with provincial recorded grain yield and compared the SOC change within different managements and climatic scenarios without attributing to any validation with observed SOC change data [20]. The county and the state-level observed yield data across the USA were used to validate the simulated crop yields here [73]. Second, the county-level estimation of $\mathrm{N}_{2} \mathrm{O}$ in another DAYCENT model study was used to compare with the model $\mathrm{N}_{2} \mathrm{O}$ prediction of this study to partially validate the results [53].

The accuracy of the model predicted emissions is also dependent on the accurate input of management data [42]. The management data were collected from various state-level agricultural reports and journal articles. The state-level practices were assumed to be able to depict a general scenario of the basin. Besides, observed yield results were compared with model yields using two of the commonly used mineral fertilizer types (urea and $\mathrm{NH}_{4} \mathrm{NO}_{3}$ ) to account for uncertainty. For example, farmers might have used $\mathrm{NH}_{4} \mathrm{NO}_{3}$, urea, both, or any other type of fertilizers to get the observed level of yield. However, for the latter analysis in this study, only the $\mathrm{NH}_{4} \mathrm{NO}_{3}$ cases were shown.

\subsection{Output Analysis}

Model outputs of this study were summarized in terms of three decision parameters: grain yield, $\mathrm{N}_{2} \mathrm{O}$, and GWP for each level of analysis. The output analysis can be seen from two perspectives here: (a) conversion of GHGs to GWP and (b) data analysis and visualization.

Conversion of GHGs data to GWP: to quantify the net effect of any alternative management practice on GHGs, the term global warming potential (GWP) was introduced rather than just quantifying $\mathrm{N}_{2} \mathrm{O}$ or $\mathrm{CO}_{2}$ (SOC depletion) emission. GWP is the total $\mathrm{CO}_{2}$ equivalent of all the GHGs considered within the system [63]. The major carbon and nitrogen related emission from the agricultural soil mainly contain $\mathrm{N}_{2} \mathrm{O}, \mathrm{NO}, \mathrm{N}_{2}, \mathrm{NH}_{3}$, $\mathrm{CH}_{4}$, and $\mathrm{CO}_{2}[35,36]$ - among which $\mathrm{N}_{2} \mathrm{O}, \mathrm{CH}_{4}$, and $\mathrm{CO}_{2}$ are classified as GHGs and are considered for the total GHGs from the agricultural soil [29]. $\mathrm{CH}_{4}$ is mainly associated with rice-based production and animal manure management and thus was ignored during the prediction of GHGs from upland agriculture of the study region [4]. Here, the comparison among the GWPs of the scenarios was conducted based on the net benefit (NB) concept in level 1. The changes in yield and $\mathrm{N}_{2} \mathrm{O}$ were expressed in terms of percent change (PC). The concept of GWP and NB is expressed by the Equations (1)-(3):

GWP (Global Warming Potential $)=\mathrm{CO}_{2}$ eq. from $\mathrm{N}_{2} \mathrm{O}+\mathrm{CO}_{2}$ eq. from SOC $+\mathrm{CO}_{2}$ eq. from $\mathrm{CH}_{4}$

$$
\text { Net Benefit }(N B)=G W P_{\text {base }}-G W P_{\text {alternative }}
$$

$$
\begin{aligned}
& \left.N B=\left[\left(N_{2} O_{\text {base }} \times \frac{44}{28} \times 298\right)+\left((-1) \times \frac{44}{12} d S O C_{\text {base }} \times 1\right)+\left(\mathrm{CH}_{4} \text { base } \times \frac{16}{12} \times 34\right)\right)\right]-\left[\left(\mathrm{N}_{2} \mathrm{O}_{\text {alternative }} \times \frac{44}{28} \times 298\right)\right. \\
& \left.+(-1) \times \frac{44}{12} d S O C_{\text {alternative }} \times 1+\left(\mathrm{CH}_{4} \text { base } \times \frac{16}{12} \times 34\right)\right]
\end{aligned}
$$

Data analysis and visualization: the methods and the statistical terms used for output analysis varied among the levels of analysis conducted. At level 1, efforts were made to calculate total regional emission from all four major cropping systems and eight management alternatives studied in this paper. The total amount of yield or emission was calculated 
by the following Equation (4): (crops 1 through 4 are the four major crops and IDU $=1$ through 147 are the IDUs).

Total Emission or Yield $=\sum_{\text {crop }=1}^{4} \sum_{I D U=1}^{147}$ Emission or Yield per unit area $\times$ Crop Acreage

The total GWP and $\mathrm{N}_{2} \mathrm{O}$ emissions for each management were visualized by GIS plots, which showed the regional amount in GHG variation as well as the spatial variation. The GHG hotspot of the whole region and its mitigation potential by varying managements were also visible from the plots (Figure A1a,b).

Additionally, at level 1 analysis, the cumulative distribution function (CDF) of the emission rate (emission/unit area) and the grain production rate (dry matter/unit area) breakdowns for each of the four crops were shown, rather than the summation of the total amount (Figure $5 \mathrm{a}-\mathrm{h}$ ). The CDF represented the cumulative probability for a given decision parameter (i.e., grain yield, $\mathrm{N}_{2} \mathrm{O}$, or GWP). $\mathrm{CDF}$ determined the probability that a random observation taken from the population was less than or equal to a certain value. The steeper the slope of the CDF curve was, the higher the probability of occurrence was within a small range of decision parameters and vice versa. Level 2 and level 3 results were mainly presented with error bar plots in which the marker, the upper ends, and the lower ends of the error bar plots represented the 50th, the 25th, and the 75th percentiles of the multi-year analysis, respectively. The horizontal axis of the plots represented the temperature plus $\mathrm{CO}_{2}$ combinations for both levels, and the color codes represent the associated precipitation and managements in level 2 and level 3, respectively. Additionally, the scenario funnel plots were added as a complement to error bar plots. The funnel plots represent the extent of predicted changes in decision parameters toward the end of the century due to all the considered climatic variations and the potential managements in level 2 and level 3, respectively. These plots were included in Figures 6-9.

\section{Results}

\subsection{Model Validation Results}

For the first step of validation with the county-level median observed yields, the absolute values of relative errors (RE) of the model prediction seemed to vary between $0.6 \%$ to $+20 \%$ for $\mathrm{NH}_{4} \mathrm{NO}_{3}$. Additionally, for the case of urea, the variation was between $2.5 \%$ to $13.4 \%$. For the regional validation, the level of error that occurred in this study was assumed to be acceptable (Table 1 and Figure 4) [20,29]. The main objective of the study was to make a comparison among the scenarios rather than predict precise field emissions. Thus, this level of validation was assumed reasonable to show the relative difference among the scenarios.

Table 1. Comparison of observed and predicted grain yields of five years (2014-2018) for four major crops of the region (RE: relative error).

\begin{tabular}{|c|c|c|c|c|c|}
\hline Case & $\begin{array}{l}\text { Observed } \\
\text { kg dm }\end{array}$ & $\begin{array}{c}\text { Predicted-NH} \mathrm{H}_{4} \mathrm{NO}_{3} \\
\text { kg dm }\end{array}$ & $\begin{array}{l}\text { Predicted-Urea } \\
\text { kg dm }\end{array}$ & $\underset{\%}{\mathrm{RE}-\mathrm{NH}_{4} \mathrm{NO}_{3}}$ & $\begin{array}{c}\text { RE-Urea } \\
\%\end{array}$ \\
\hline Corn & 8122.4 & 8072.0 & 7108.9 & -0.6 & -12.5 \\
\hline Soybean & 2367.2 & 2684.0 & 2684.0 & 13.4 & 13.4 \\
\hline Cotton & 907.9 & 1090.8 & 845.3 & 20.1 & -6.9 \\
\hline Peanut & 3692.6 & 3601.1 & 3601.1 & -2.5 & -2.5 \\
\hline
\end{tabular}




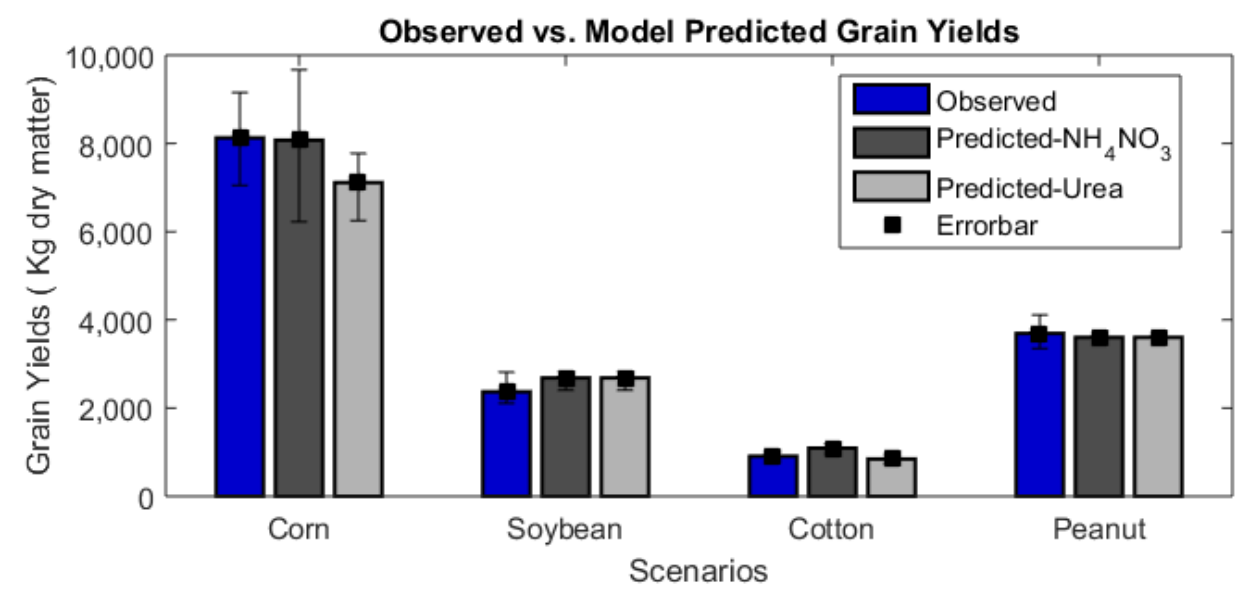

Figure 4. Comparison of observed and predicted grain yields of 5 years (2014-2018) for four major crops and two fertilizer types.

For the second step, the counties intersecting the study region were seen to have an $\mathrm{N}_{2} \mathrm{O}$ emission level of $0.5-1.5 \mathrm{kgN} / \mathrm{ha}$ according to the DAYCENT model county-level emission estimates [53]. Since the model $\mathrm{N}_{2} \mathrm{O}$ estimates here were also close to that range, it provided increased confidence in the model predictions.

\subsection{Level 1: Impacts of the Alternative Managements in the Present Climate}

The results of level 1 analysis are provided as (a) GIS plots (Figure A1) to represent the effects of the eight management practices as well as total shifts in grain yields, $\mathrm{N}_{2} \mathrm{O}$ emissions, and GWPs for all the four major crops. Additional results are displayed as (b) CDF plots to show the probability distribution of emission rates or yield rates for each of the crops separately (Figure 5 ).

The GIS plots and Table 2 (calculated from Equation (4), Section 2.9) indicated that the total percent changes of grain yields between alternatives and base management varied between $-1.2 \%$ and $5.2 \%$ for the $50 \%$ fertilizer replacement scenario and the $2000 \mathrm{kgC} / \mathrm{ha}$ manure amendment scenario, respectively. Other management scenarios than the $50 \%$ fertilizer replacement scenario showed slight positive changes in the total yields of the whole basin (Table 2). From the emission perspective, the total $\mathrm{N}_{2} \mathrm{O}-\mathrm{N}$ emissions were seen to be elevated in all the scenarios relative to the baseline, and the variation is pictorially represented in Figure A1. The highest increase of $124 \%$ was seen to be associated with the $2000 \mathrm{kgC} / \mathrm{ha}$ manure addition scenario followed by a $56 \%$ increase in the $1000 \mathrm{kgC} / \mathrm{ha}$ manure addition scenario. On the other hand, the replacement of mineral fertilizer with $1000 \mathrm{kgC} /$ ha manure and no-till combined with $15 \%$ residue incorporation seemed to perform relatively better with a lower increase in $\mathrm{N}_{2} \mathrm{O}-\mathrm{N}$ emissions (Table 2 and Figure A1a). Finally, the total GWPs (primary decision parameter) showed the highest NBs in manure as well as fertilizer replacement scenarios and the lowest in no-till scenarios (Figure A1b). Moreover, the GIS plots showed the hotspot of the agricultural emissions in the region and their treatment alternatives. 


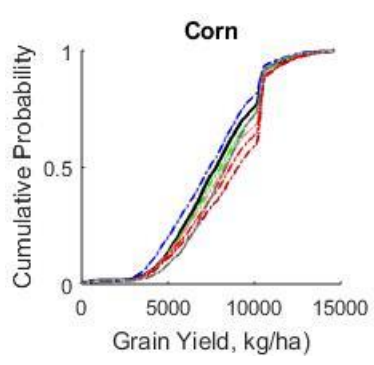

(a)

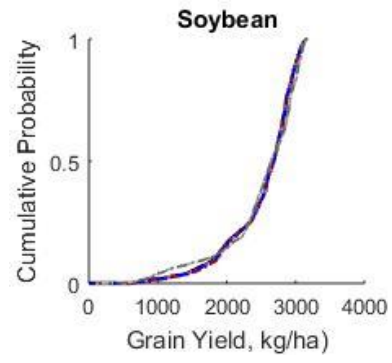

(b)

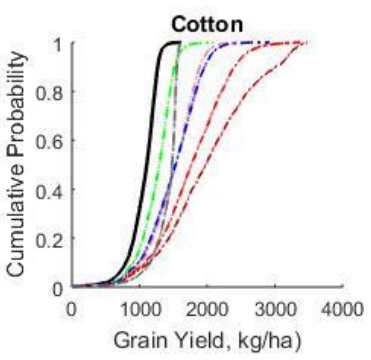

(c)

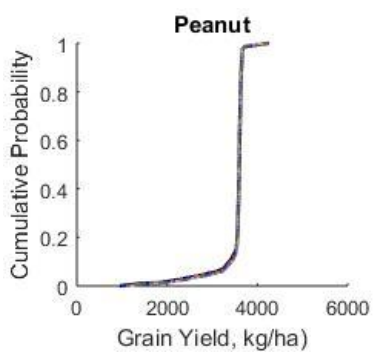

(d)

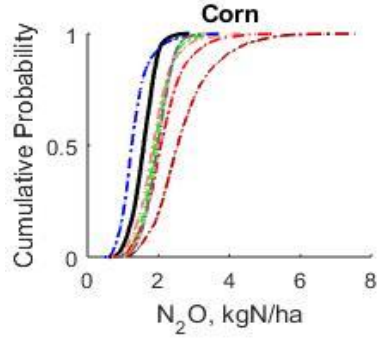

(e)

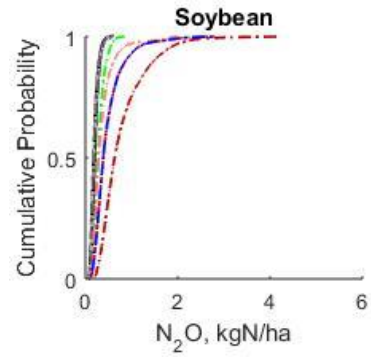

(f)

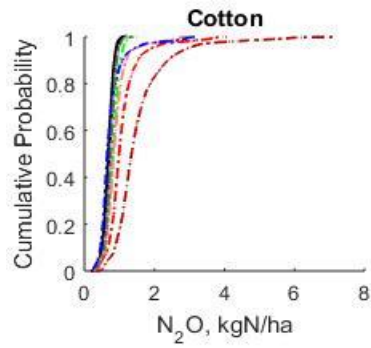

(g)

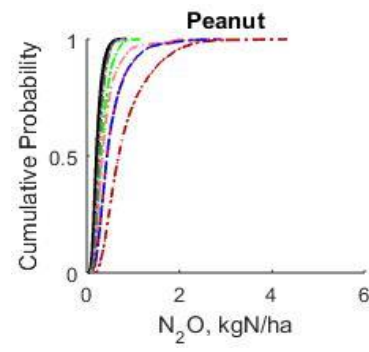

(h)

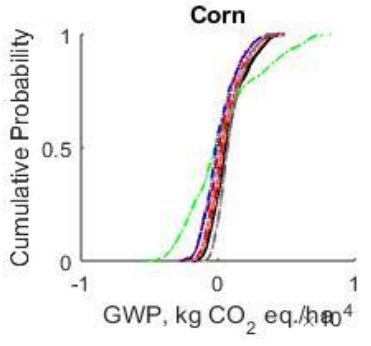

(i)

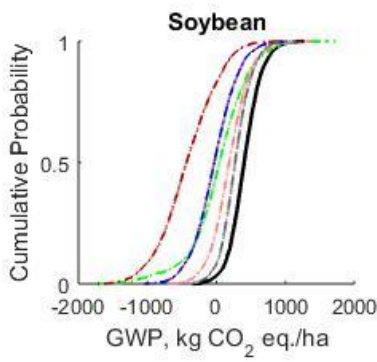

(j)

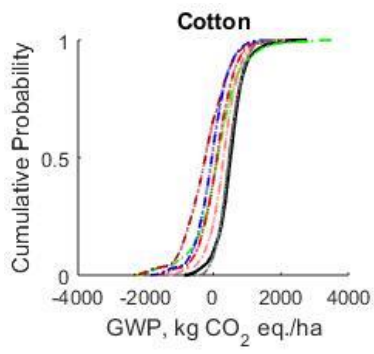

(k)

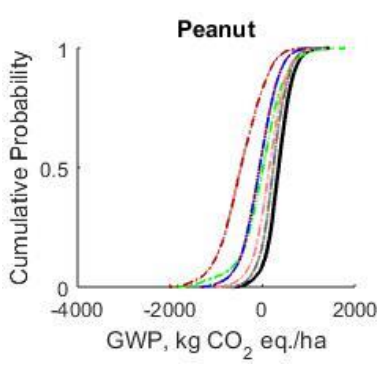

(1)

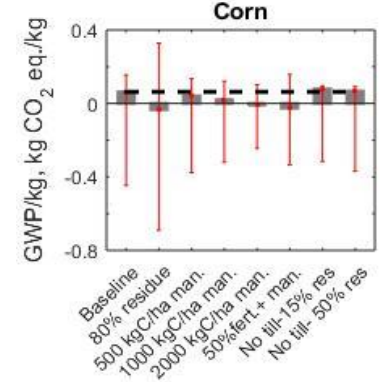

(m)

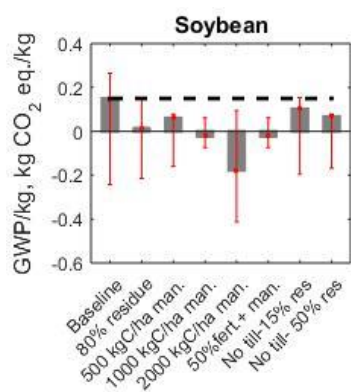

(n)

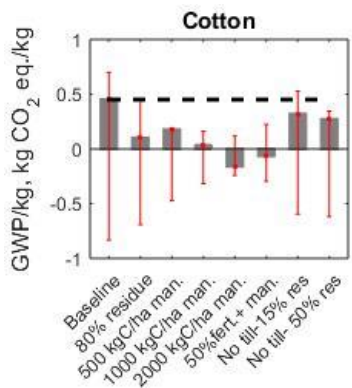

(o)

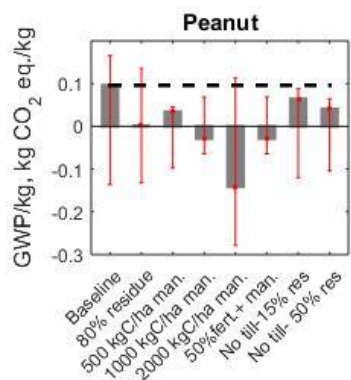

(p)

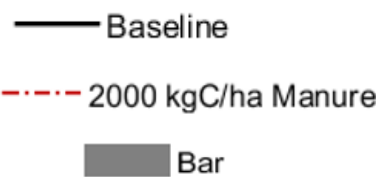

$1000 \mathrm{kgC} / \mathrm{ha}$ Manure

No till-15\% residue

- - - Baseline

Figure 5. Cumulative distribution (CDF) plots of (a-d) grain yields, (e-h) $\mathrm{N}_{2} \mathrm{O}$ emissions, (i-1) global warming potentials (GWPs), and ( $\mathbf{m}-\mathbf{p})$ error bar plots of global warming potential per unit grain (GWP/kg grain) productions for four major crops of the Choctawhatchee Basin. 
Table 2. Median GWP, $\mathrm{N}_{2} \mathrm{O}$, and grain yield totals for four major crops of the Choctawhatchee Basin (MT: metric ton).

\begin{tabular}{|c|c|c|c|c|c|c|c|c|c|}
\hline Parameters & Unit & Baseline & $\begin{array}{c}80 \% \\
\text { Residue }\end{array}$ & $\begin{array}{c}500 \\
\mathrm{kgC} / \mathrm{ha} \\
\text { Manure }\end{array}$ & $\begin{array}{c}1000 \\
\mathrm{kgC} / \mathrm{ha} \\
\text { Manure }\end{array}$ & $\begin{array}{c}2000 \\
\mathrm{kgC} / \mathrm{ha} \\
\text { Manure }\end{array}$ & $\begin{array}{c}50 \% \text { Fer- } \\
\text { tilizer+ } \\
\text { Manure }\end{array}$ & $\begin{array}{c}\text { No-Till- } \\
15 \% \\
\text { Residue }\end{array}$ & $\begin{array}{c}\text { No-Till- } \\
50 \% \\
\text { Residue }\end{array}$ \\
\hline GWP (total) & Thousand $\mathrm{MT} \mathrm{CO}_{2}$ eq. & 36.1 & 0.23 & 18.2 & 0.18 & -29.1 & -0.53 & 30.9 & 23.9 \\
\hline GWP (NB) & Thousand MT $\mathrm{CO}_{2}$ eq. & 0 & 33.7 & 17.8 & 34.3 & 65.1 & 41.3 & 0.51 & 0.12 \\
\hline $\mathrm{N}_{2} \mathrm{O}$ (total) & MT kg N eq. & 41 & 53 & 53 & 64 & 92 & 50 & 49 & 62 \\
\hline $\mathrm{N}_{2} \mathrm{O}$ (\% change) & $\%$ & $0 \%$ & $29 \%$ & $29 \%$ & $56 \%$ & $124 \%$ & $21 \%$ & $20 \%$ & $51 \%$ \\
\hline Grain (total) & Thousand MT grain eq. & 338 & 343.2 & 348.5 & 352.8 & 355.5 & 333.9 & 344.7 & 347.1 \\
\hline Grain (\% change) & $\%$ & 0 & $1.5 \%$ & $3 \%$ & $4 \%$ & $5.2 \%$ & $-1.2 \%$ & $2 \%$ & $2.7 \%$ \\
\hline
\end{tabular}

The CDF plots for the cropping systems with eight managements practices revealed that the rate of grain yields mainly increased for the alternative management scenarios for the two non-legume crops (i.e., corn and cotton) and remained almost unchanged for the two legume crops (i.e., soybean and peanut) - with a few exceptions in the no-till with $15 \%$ residue addition scenario in cotton and fertilizer reduction scenario in corn (Figure 5a-d). The increase in yield rate was more evident for the primary cropping practice (i.e., cotton) in the studied region. However, the $\mathrm{N}_{2} \mathrm{O}$ emission rates were seen to increase for most of the alternative management cases, which was consistent with the total emission results mentioned in the first part. High manure incorporation scenarios showed the highest $\mathrm{N}_{2} \mathrm{O}$ emission rates for all the cropping systems (Figure 5e-h).

On the contrary, the GWP rates decreased with the incorporation of alternative managements, where high manure incorporation was associated with lower GWPs. For almost all the scenarios, these phenomena were visible, with some exception in the cases of NTs in corn and cotton. Again, as the alternative management scenarios (especially the scenarios with manure incorporation) increased the grain yields and decreased the GWP, they were seen to reduce the GWP $/ \mathrm{kg}$ of grain production. This phenomenon was also quite visible in the bar plots, where the normalized GWPs (GWPs/unit grain) were presented (Figure $5 \mathrm{~m}-\mathrm{p}$ ). The bar plots clearly showed how the GWP $/ \mathrm{kg}$ grain yields were negative for high manure and fertilizer replacement cases for all the analyzed crops except no-tillage scenarios of corn. However, NT-related scenarios for other crops were also less beneficial compared to other management scenarios in terms of GWP $/ \mathrm{kg}$ grain yield. For the summary, the percent change values $\left(\mathrm{N}_{2} \mathrm{O}\right.$ and grain yield rates) and the NBs (GWP rates) associated with each of the scenarios are presented in Table S5.

\subsection{Level 2: Impacts of the Climate Change on the Base Management}

The modeled impacts of the plausible climate change were represented by (a) error-bar plots as well as (b) funnel plots in this level to represent the patterns of variations and the extent of changes in the decision parameters with the plausible changes in climatic variables (Figures 6 and 7). However, from the error bar plots of level 2 analysis, the grain yields seemed to be more impacted by temperature- $\mathrm{CO}_{2}$ combinations rather than precipitation (except $-40 \%$ precipitation case) from an overall point of view. The most general patterns were the decreases in yields (except corn base and the additive precipitation scenarios) with increasing temperatures and the significant increases in yields with increasing $\mathrm{CO}_{2}$ concentrations (Figure $6 \mathrm{a}-\mathrm{d}$ ). There were clear positive shifts in yields during the two shifts of $\mathrm{CO}_{2}$ concentrations (i.e., $370 \mathrm{ppm}$ to $538 \mathrm{ppm}$ and $538 \mathrm{ppm}$ to $936 \mathrm{ppm}$ ). The precipitation impacts seemed to be clustered with very close values (except $-40 \%$ precipitation) and the most general patterns showed that both excess increase and decrease in precipitation reduced the grain yields. The highest reductions in yields were caused by a $6{ }^{\circ} \mathrm{C}$ increment in temperature and a $40 \%$ reduction in the amount of precipitation. The $40 \%$ reduced precipitation impacted the corn mostly with $3000 \mathrm{~kg}$ grain loss in the base timeline, and the least impact was seen in peanut. The $+6{ }^{\circ} \mathrm{C}$ temperature extreme caused significant reductions in yields for all the management scenarios compared to the other temperature shifting cases with around $50 \%$ or more yield loss as impacts (Figure 6a-d). At this level, the changes of $\mathrm{N}_{2} \mathrm{O}-\mathrm{N}$ fluxes due to the changes in climatic components provided very clear changing trends with changes in all climatic components. Evidently, the precipitation had 
far more impact on $\mathrm{N}_{2} \mathrm{O}$ emissions than the temperature- $\mathrm{CO}_{2}$ concentration combination. The pattern with precipitation was significant increases and decreases in each $\mathrm{N}_{2} \mathrm{O}-\mathrm{N}$ scenario with an increase and a decrease in precipitation, respectively. The temperature was also positively correlated with $\mathrm{N}_{2} \mathrm{O}-\mathrm{N}$, where $\mathrm{CO}_{2}$ showed a slight negative correlation (mostly visible in cotton and soybean). All the increased precipitation conditions significantly increased the $\mathrm{N}_{2} \mathrm{O}-\mathrm{N}$ emissions compared to the base points and vice versa (Figure $6 \mathrm{e}-\mathrm{h}$ ). Here, the primary decision parameter, GWP (both per unit area and per unit grain), was impacted by all the climatic components considered. The pattern should not be simply generalized for all the crops as those of the prior two decision parameters. Inter-crop variability was quite visible in this case. Corn showed more clear impacts of the temperature changes than the changes in the precipitation and $\mathrm{CO}_{2}$, unlike the other cropping scenarios. The GWPs (per unit area) of the other crops had significant shifts with precipitation change while maintaining almost similar changing patterns with temperature- $\mathrm{CO}_{2}$ combinations. Positive correlations of GWPs and temperature- $\mathrm{CO}_{2}$ concentrations were clearly visible in the cases of soybean, cotton, and peanut. Additionally, the general correlation of GWP was positive with temperature and precipitation and negative with atmospheric $\mathrm{CO}_{2}$, such as the $\mathrm{N}_{2} \mathrm{O}$ case. However, the slight decreases in GWPs were visible for soybean and cotton from the temperature extremes of $+4.5^{\circ} \mathrm{C}$ to $+6{ }^{\circ} \mathrm{C}$, which were attributed to the unknown complex interactions (Figure $6 \mathrm{~m}-\mathrm{p}$ ). GWPs per unit grain yield showed an almost similar pattern with GWPs per unit area. As there was a significant reduction of corn yield in base time, that was also visible in this parameter, which was not visible in GWP per unit area alone.

The funnel plots (Figure 7) of the grain yield of two legume crops (i.e., peanut and soybean) showed that the projection funnel boundaries were mostly deflected downward from the reference line in response to extreme temperature increment of $+6{ }^{\circ} \mathrm{C}(-1500 \mathrm{~kg}$ decrease in yield for both legume crops). Change in yields varied approximately from $-500 \mathrm{~kg}$ to $500 \mathrm{~kg}$ for soybean and almost no change for peanut. Additionally, the change in corn varied from $-3500 \mathrm{~kg}$ to $1600 \mathrm{~kg}$, whereas cotton showed the range of change from $-140 \mathrm{~kg}$ to $+180 \mathrm{~kg}$ (Figure $7 \mathrm{a}-\mathrm{d}$ ). The most evident pattern was the association of the higher temperature and the lower precipitation scenarios with a negative change in yield. For the $\mathrm{N}_{2} \mathrm{O}$ emission cases, all the crops had scenario funnel slightly deflected toward the upward direction. The inter-crop variability in the changing amounts was different with the highest change for corn followed by peanut, soybean, and cotton (Figure 7e-h). The lower temperatures, the higher $\mathrm{CO}_{2}$ concentrations, and the lower precipitation caused the downward shifts and vice versa. However, the GWP (per unit area) funnels for soybean, corn, and cotton were approximately symmetric toward upward or downward change, while corn had a slight upward deflection. The patterns of climatic components were almost similar to those of $\mathrm{N}_{2} \mathrm{O}$ changing patterns. The highest GWP change was seen for corn with the approximate range of $-220 \mathrm{~kg} \mathrm{CO}_{2} \mathrm{eq}$./ ha to $700 \mathrm{~kg} \mathrm{CO}$ eq./ha, whereas soybean, cotton, and peanut seemed to vary between $-170 \mathrm{~kg} \mathrm{CO}$ eq. $/ \mathrm{ha}$ and $170 \mathrm{~kg} \mathrm{CO}$ eq. $/ \mathrm{ha},-210 \mathrm{~kg} \mathrm{CO}$ eq./ha and $190 \mathrm{~kg} \mathrm{CO}$ eq. $/ \mathrm{ha}$, and $-180 \mathrm{~kg} \mathrm{CO}$ eq. $/ \mathrm{ha}$ and $220 \mathrm{~kg}$ $\mathrm{CO}_{2}$ eq./ha, respectively (Figure 7i-l). The GWPs (per unit grain) showed asymmetric funnels deflected toward upper ends as the grain yield funnels were deflected downward. Based on all the decision parameters and considering ranges of future climatic uncertainties (Figure 7m-p), the GWP bounds were deflected mostly in the upward direction, which supported a relatively greater negative impact on climate change toward the future timeline. In this region, the corn yield was most expensive in terms of GWP, whereas other crops had similar GWP costs per unit grain production. 
(a)

(b)
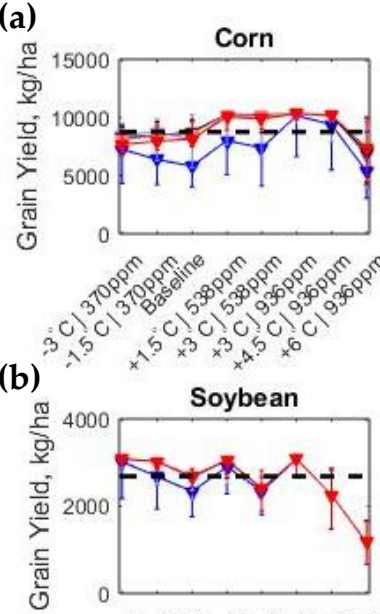

c)

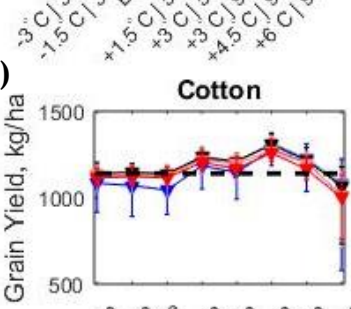

$=x^{3} x^{5} x^{3} x^{3} x^{5} x^{6}$

(d)

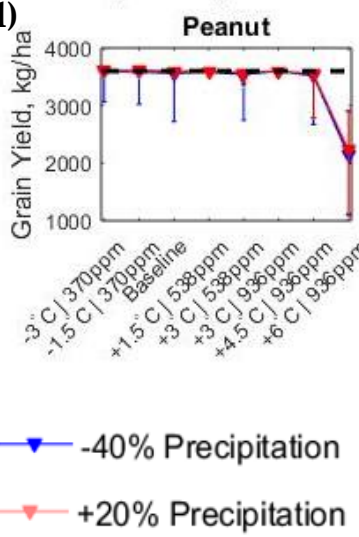

(e)

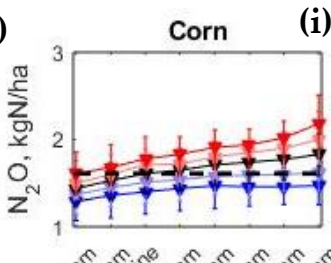

(f)

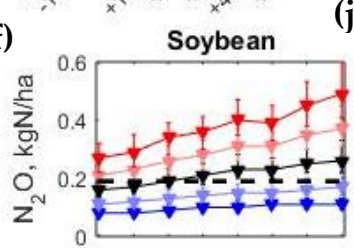

(j)

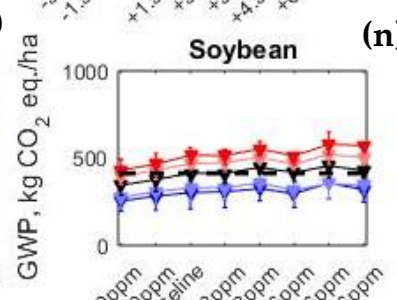

$\sum_{0}^{2}$

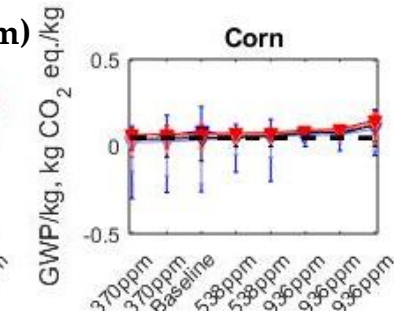

(n)
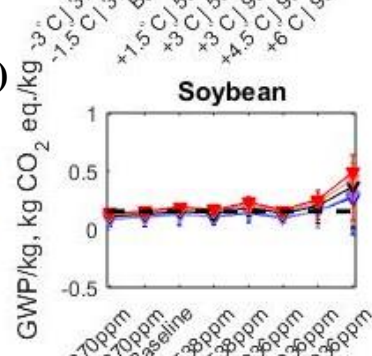

(k)
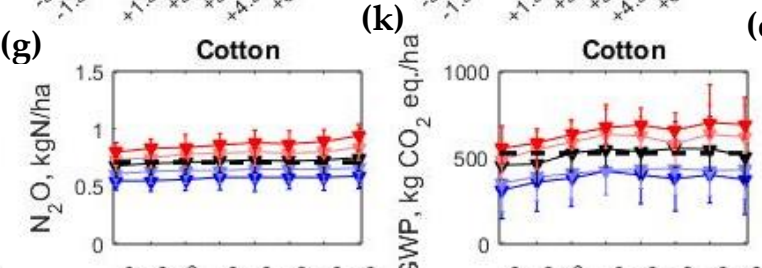

(o)
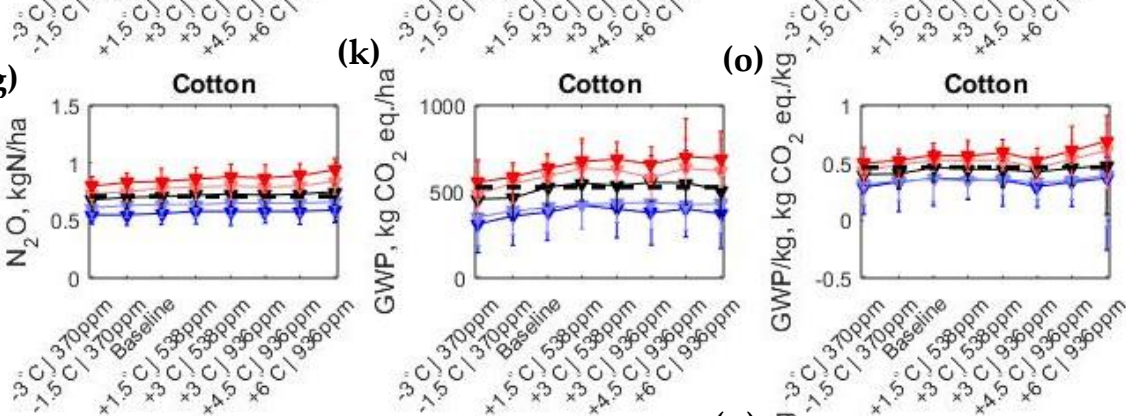

(h)

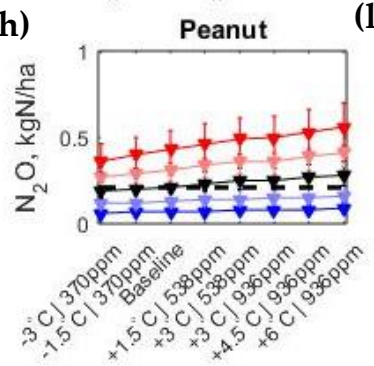

(1) 뚣
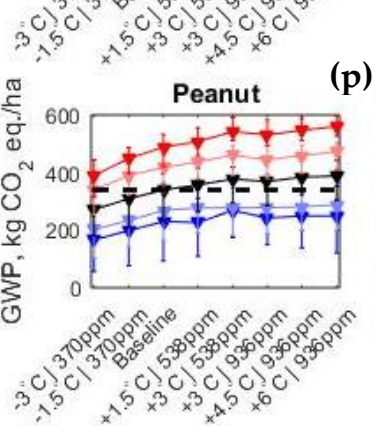

(p)
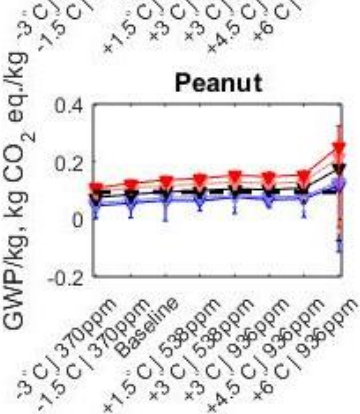

$\checkmark$ Base Precipitation

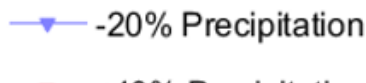

- - -Baseline

Figure 6. Assessing the impact of climate change on the base management for the four major crops of the Choctawhatchee Basin by the determination of (a-d) grain yields, (e-h) $\mathrm{N}_{2} \mathrm{O}$ emissions, (i-l) GWPs, and ( $\left.\mathbf{m}-\mathbf{p}\right)$ GWPs/kg grain scenarios. 

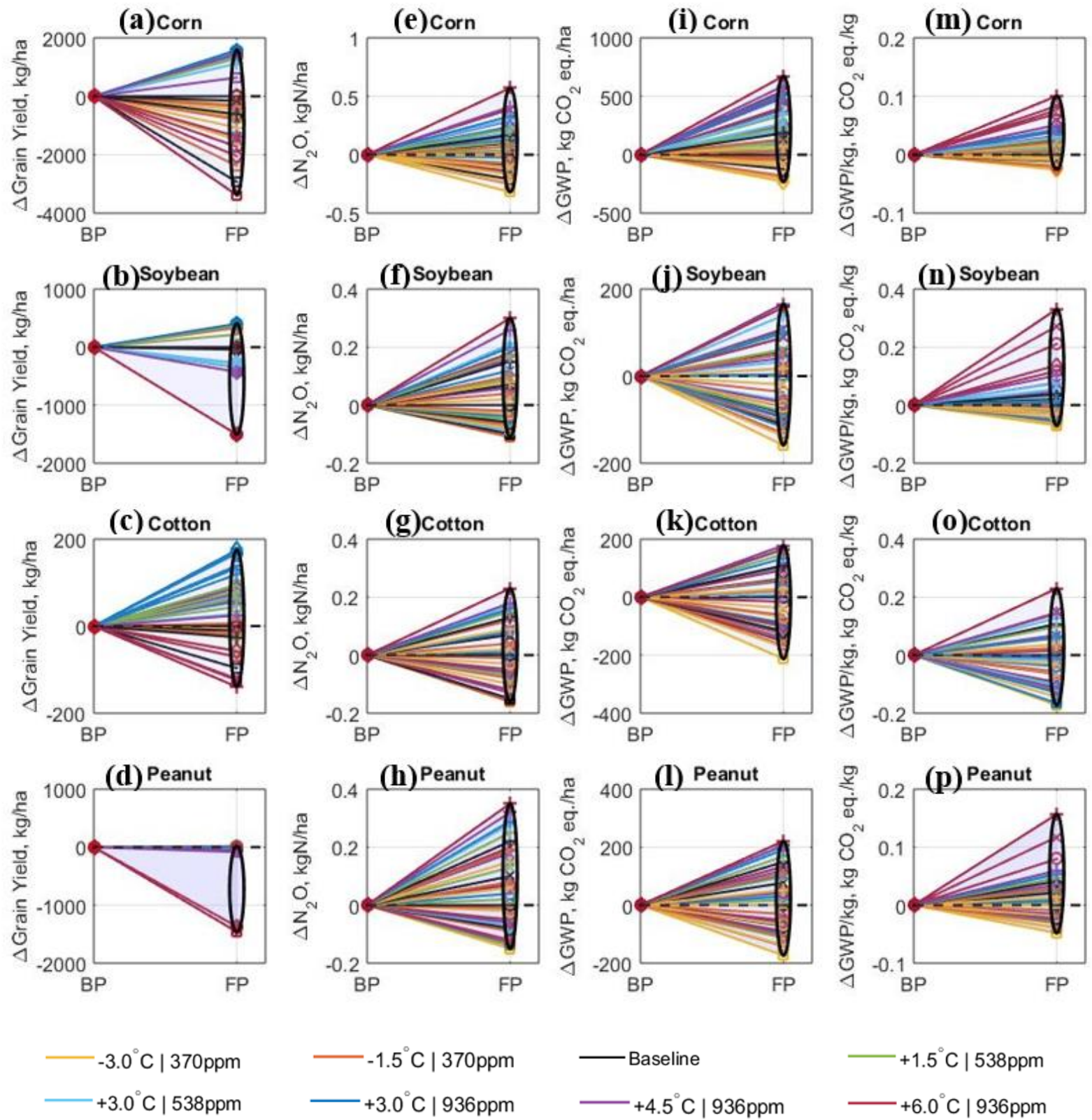

Figure 7. The projected changes of the decision parameters ((a-d) grain yields, (e-h) $\mathrm{N}_{2} \mathrm{O}$ emissions, (i-l) GWPs, and $(\mathbf{m}-\mathbf{p})$ GWPs $/ \mathrm{kg}$ grain)) from the present toward the future for the four major crops of the Choctawhatchee Basin (BP: base point, FP: future projection, $\Delta$ : change).

\subsection{Level3: Impacts of the Alternative Managements in the Projected Climate Change}

The results of level 3 enabled choosing the managements that had the potential to mitigate the negative impact of GHGs, which was assessed in the level 2 analysis of this study (Figures 8 and 9). From the error-bar plots (Figure 8), the grain yields seemed to increase with the positive shifts in atmospheric $\mathrm{CO}_{2}$ in climate combination $4\left(1.5^{\circ} \mathrm{C}+538 \mathrm{ppm}\right)$ and combination $6\left(3{ }^{\circ} \mathrm{C}+936 \mathrm{ppm}\right)$. At constant $\mathrm{CO}_{2}$ as well as increasing temperature (i.e., combinations $1,2,3$, and combinations $6,7,8$ ), the negative shifts in yields were evident in most of the cases. The crop yields affected by $+5{ }^{\circ} \mathrm{C}$ to $+6{ }^{\circ} \mathrm{C}$ temperature increments were seen to be hardly compensated with the benefit due to the $\mathrm{CO}_{2}$ increase in this study. The patterns of the shifts among the managements were mostly visible in cotton, partially visible in corn, and not visible in the other two legume crops. Here, the emission of $\mathrm{N}_{2} \mathrm{O}$ from each case showed a clear pattern of increase with increases in temperature 
and $\mathrm{CO}_{2}$ (except for a few instances, especially corn and cotton) (Figure 8e-h). The GWPs showed non-significant increasing trends or irregular trends among the climate shifting scenarios (Figure 8i-1). However, the differences with management were quite evident in the cases of GWPs. For GHG emissions, the management seemed to dominate over changes due to climatic shifts as per the model prediction of this study. As with the present scenarios, the manure-based managements and the residue incorporation provided better NBs over other options for the plausible future climatic conditions with slight dissimilarities among the crop types.
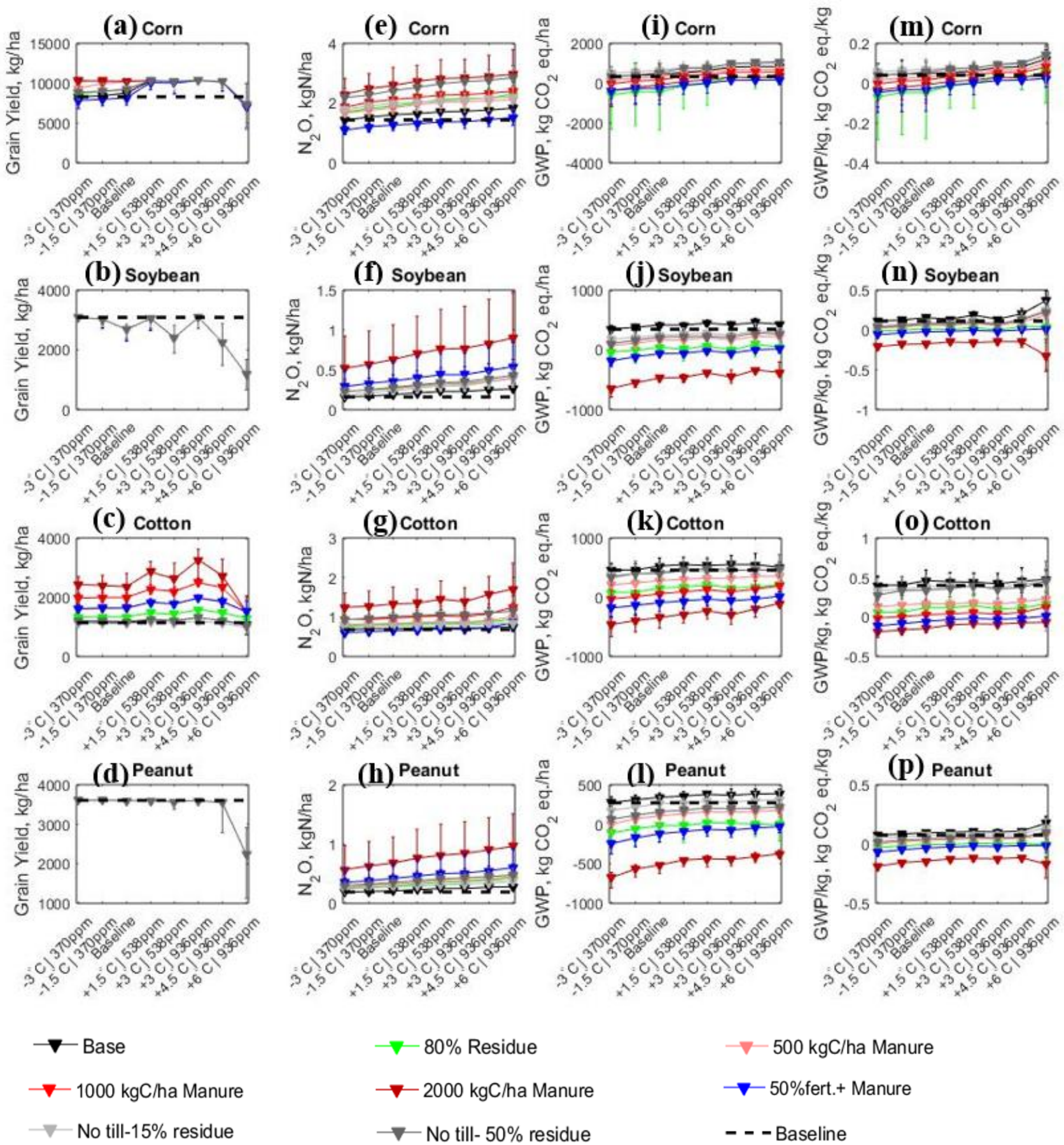

Figure 8. Assessing the behavior of alternative management practices in the projected future climatic scenarios for the four major crops of the Choctawhatchee Basin by the determination of (a-d) grain yields, (e-h) $\mathrm{N}_{2} \mathrm{O}$ emissions, (i-l) GWPs, and $(\mathbf{m}-\mathbf{p})$ GWPs $/ \mathrm{kg}$ grain scenarios. 
The scenario funnels (Figure 9) with grain yields of peanut and soybean were mostly deflected downward, indicating higher reductions of the grain yields of the crops by several management options in the plausible future condition. Cotton grain yield funnel was mostly upward-directed (manure increased the yield most, followed by $50 \%$ replacement fertilizer with manure and residue incorporation) except for the no-till incorporation cases. Corn yield showed an approximate symmetric spread, where the $50 \%$ fertilizer plus manure scenario seemed to cause both positive or negative changes depending on temperature- $\mathrm{CO}_{2}$ combinations (Figure $9 \mathrm{a}-\mathrm{d}$ ). The scenario funnels for all the $\mathrm{N}_{2} \mathrm{O}$ scenarios showed higher upward deflection, indicating the higher likelihood of plausible increases with managements. For all the crops, the higher manure incorporation was responsible for the highest increases, and the 50\% fertilizer plus manure (cotton and corn), the baseline (soybean and peanut), and sometimes the no-till with $15 \%$ or $50 \%$ residue incorporations (soybean and peanut) scenarios seemed to be associated with lower increases or reductions in $\mathrm{N}_{2} \mathrm{O}$ emissions (Figure 9e-h). Unlike the $\mathrm{N}_{2} \mathrm{O}$ cases, the GWPs of soybean, cotton, and peanut seemed to be positively changed (downward deflection indicating GWP reduction) by the adaptation of alternative management practices in the plausible future climate. The GWP of corn showed an almost symmetric pattern, indicating similar extents in positive or negative change. The high manure incorporation seemed to be involved with higher GWP reduction for soybean, cotton, and peanut, where the residue incorporation was associated with the highest GWP reduction in the case of corn (Figure 9i-1). Besides, the GWP $/ \mathrm{kg}$ grain yield showed higher upward, higher downward, symmetric, and higher downward extents for corn, cotton, soybean, and peanut, respectively. Irrespective of crops, the baseline and the no-tillage scenarios were associated with higher GWPs $/ \mathrm{kg}$ grain. The lower GWPs $/ \mathrm{kg}$ grain scenarios were associated with high manure and fertilizer replacement scenarios for soybean, cotton, and peanut, where corn had lower GWP $/ \mathrm{kg}$ grain associated with residue incorporation and fertilizer replacement. These results indicated the potential management for each of the major crops of the basin (Figure $9 \mathrm{~m}-\mathrm{p}$ ). 

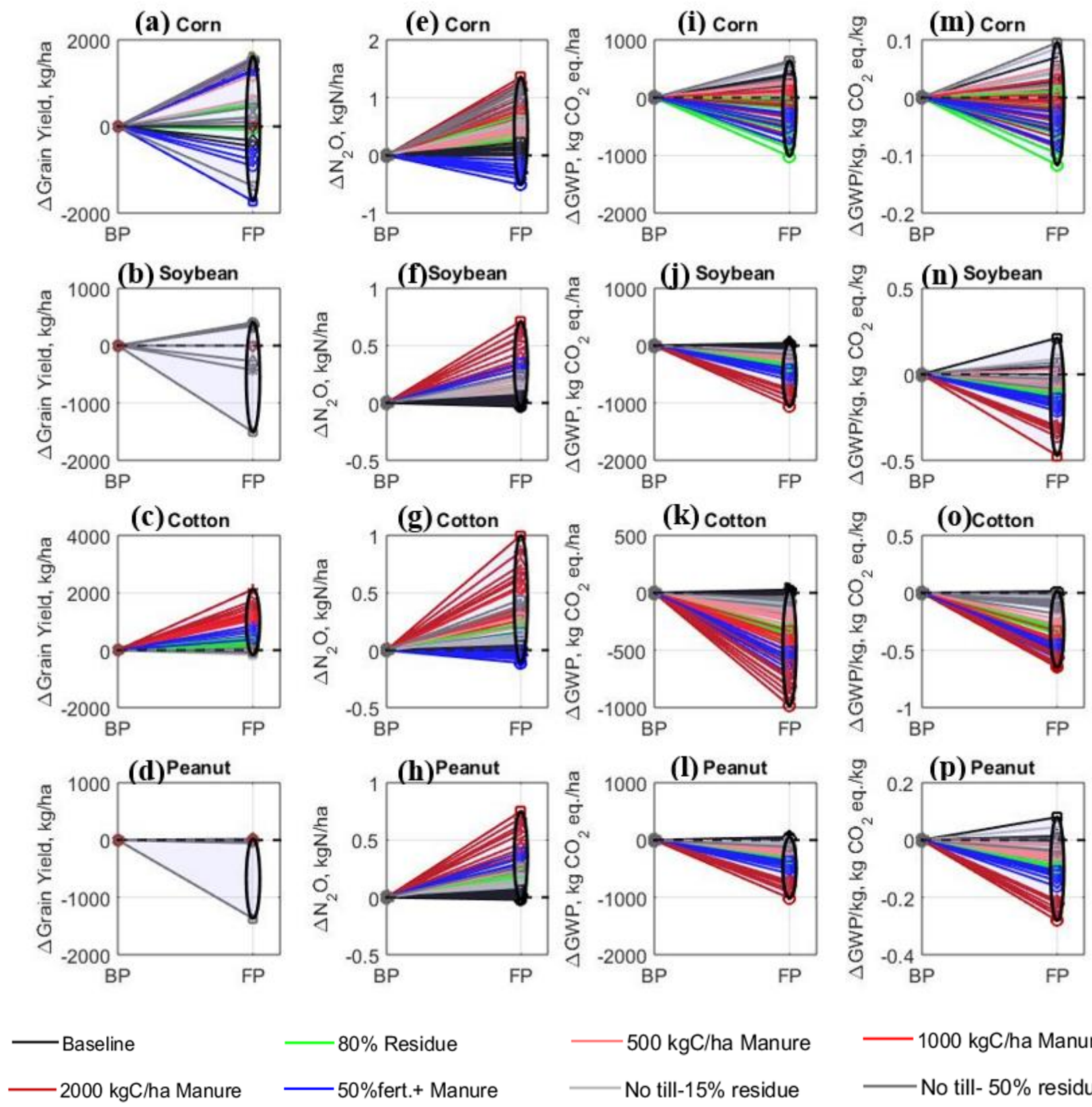

No till-15\% residue

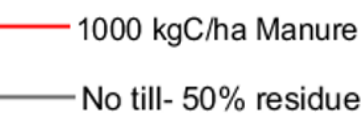

Figure 9. The projected changes of the decision parameters ((a-d) grain yields, (e-h) $\mathrm{N}_{2} \mathrm{O}$ emissions, (i-1) GWPs, and ( $\mathbf{m}-\mathbf{p})$ GWPs/kg grain)) under varying management practices in the future plausible climatic condition for the four major crops of the Choctawhatchee Basin (BP: base point, FP: future projection, $\Delta$ : change).

\section{Discussion}

\subsection{Plausible Impact of Climate Change on the Cropping System of the Basin}

The whole agricultural ecosystem can significantly vary with varying climatic components: temperature, precipitation, and $\mathrm{CO}_{2}$, etc. The grain yield and the GHGs can both be potentially altered in positive or negative directions depending on the amount of change in climatic components $[30,74,75]$.

As for the impact of climate change on yields, the most evident pattern (in the level 2 analysis) was the association of extreme precipitation (extreme increase or decrease) and the higher temperature (extreme increase) scenarios with negative changes in yield, in addition to the positive changes in yield with increased atmospheric $\mathrm{CO}_{2}$ concentration due to its fertilization effect. The likely causes of these negative impacts of precipitation extremes 
on yields were negative impacts of fertilizer leaching and water scarcity by increased and decreased precipitation events, respectively [76]. In fact, as per Eekhout et al. (2018), the increased precipitation can also potentially risk water security due to redistribution of water between soil and surface, causing plant water stress as well as yield decreases [77]. Besides, Deryng et al. (2014) clearly showed the impact of temperature extremes by analyzing 72 climate projections (mainly RCPs) on maize, where $12.8 \pm 6.7 \%$ yield loss was caused despite the positive fertilization effect due to $\mathrm{CO}_{2}$ increase under RCP 8.5 [78]. Similarly, these types of impacts of precipitation extremes as well as temperature extremes were found in many previous studies [79-81]. As for the impact of increasing $\mathrm{CO}_{2}$ concentration, it could increase the water use efficiency of crops by better growth of root, improved canopy closure efficiency, photosynthesis, and fertilization effect-which had the potential to compensate for the affected yield by the temperature increase even above the optimal ranges. However, beyond a certain toleration extent, the yield decreased even if there was an increase in $\mathrm{CO}_{2}[78,82]$. Similarly, the crop yields affected by $+5{ }^{\circ} \mathrm{C}$ to $+6{ }^{\circ} \mathrm{C}$ temperature increments in this study were seen to be hardly compensated with the benefit due to the $\mathrm{CO}_{2}$ increase, which indicated these temperatures to be beyond the toleration limit for the studied cropping cases (Figures 6-9). Another study also strengthened the fact by claiming that South American cotton and Central American maize were 40-90\% and 30-55\% sensitive to the yield changes in response to elevated $\mathrm{CO}_{2}$ amounts of $600-700$ ppm from 330-350 ppm base level [83]. However, even if there was a potential increase in yield with increased $\mathrm{CO}_{2}$ concentrations, depending on combined temperature- $\mathrm{CO}_{2}$-precipitation scenarios, the quality of the grain might be hampered by a decrease in protein (10-14\%) and minerals (iron and zinc) in the grain due to fast growth, early flowering, fruiting, and reduced water use effect $[84,85]$. This is also an added concern for the future.

As for the impact of extreme climatic components on GHGs, Schaufler et al. (2010) found increased $\mathrm{N}_{2} \mathrm{O}$ emissions under increased temperature and moisture in several experimental sites of Europe. He also found the highest $\mathrm{CO}_{2}$ increase under increased temperature and intermediate moisture [86]. Similarly, across the datasets of a global meta-analysis on 46 publications, increases of $33 \%$ and $55 \%$ in terrestrial $\mathrm{N}_{2} \mathrm{O}$ emissions were found under raised temperature and precipitation, respectively [15], which justified the increased $\mathrm{N}_{2} \mathrm{O}$ emissions under elevated temperature and precipitation as well as the higher changes due to extreme precipitation in most of the scenarios in this study. Like the $\mathrm{N}_{2} \mathrm{O}$ emissions, the GWPs $\left(\mathrm{N}_{2} \mathrm{O}\right.$ plus $\mathrm{CO}_{2}$ emissions as $\mathrm{CO}_{2}$ equivalent $)$ followed almost the same pattern in this study, which can be further justified by different levels of positive correlations among temperature, moisture, and soil $\mathrm{CO}_{2}$ effluxes claimed in various previous studies, even though the impact of elevated temperature and moisture on soil $\mathrm{CO}_{2}$ emission (decreased C-sequestration) can be highly variable and complex [86-88]. Next, the effect of increased atmospheric $\mathrm{CO}_{2}$ concentration may impact $\mathrm{N}_{2} \mathrm{O}$ emission in mainly two ways: (1) increased plant water use efficiency $\rightarrow$ substrate availability $\rightarrow$ higher microbial activity $\rightarrow$ stimulated denitrification with $\mathrm{N}_{2} \mathrm{O}$ generation, or (2) increased plant $\mathrm{C}$ assimilation $\rightarrow$ widened litter $\mathrm{C}: \mathrm{N}$ ratios $\rightarrow$ slower decomposition $\rightarrow$ decreased substrate availability $\rightarrow$ reduced denitrification as well as $\mathrm{N}_{2} \mathrm{O}$ generation $[89,90]$. Therefore, the slight decreases in $\mathrm{N}_{2} \mathrm{O}$ emissions as wells as GWPs in response to atmospheric elevated $\mathrm{CO}_{2}$ cases in level 2 and level 3 analysis in this study might have been caused by the later process mentioned (Figures 6 and 8). The increased $C$ sequestration potential in elevated atmospheric $\mathrm{CO}_{2}$ possibly also aided this phenomenon [91,92].

\subsection{Design of Adaptation Strategies with Alternative Management Practices}

Agricultural emissions and grain yield can highly vary in various managements and climatic conditions $[29,32,45,63,93,94]$. Here, alternative management options such as the adaptation strategies for the present as well as changed climatic conditions based on the results of level 1 and level 3 analysis are discussed (Table 2, Figures 5, 8, 9 and A1).

Grain yield is significantly dependent upon $\mathrm{N}$ availability, which is mainly controlled by $\mathrm{N}$ input, available soil moisture, and net $\mathrm{N}$ mineralization [37]. Thus, increasing the $\mathrm{N}$ 
availability by the addition of $\mathrm{N}$ fertilizer, manure, and residue incorporation can positively impact the yield when added up to the optimum amount required by the crop [93-96], which is highly consistent with higher increases in yield found with higher manure and residue application and vice versa. Variable impacts-positive, negative, and similarwere seen for the reduced till cases in the previous studies, which also justifies the slightly positive, the slightly negative, and the moderately positive impacts (cotton) found in this study for different cropping cases [28]. Additionally, the patterns of the yield shifts among the managements were mostly visible in cotton, partially visible in corn, and not visible in the other two legume crops. This was because legume crops were able to produce almost maximum grain yield in the baseline condition $[97,98]$. Thus, the addition of further $\mathrm{N}$ via alternative management did not increase the yield after a certain optimum.

In the case of $\mathrm{N}_{2} \mathrm{O}$ emissions, the addition of inorganic $\mathrm{N}$ in the form of fertilizer, manure, and legume crop residues can cause a significant rise when combined with soil moisture and available C [99]; this fact is consistent with the findings of this study (Figures A1a and 5e-h) and many previous studies [28,63,93,100-102]. Manure has the potential to increase the $\mathrm{N}_{2} \mathrm{O}$ by increasing the amounts of both available $\mathrm{C}$ and $\mathrm{N}$ [103]. Additionally, crop residue-related managements such as straw incorporation and tillage with varying residues proved to be effective in altering the $\mathrm{N}_{2} \mathrm{O}$ emission pattern by changing nutrient supply, moisture retention, and soil disturbances [99,103]. For instance, a slightly lower $\mathrm{N}_{2} \mathrm{O}$ emission was observed in sandy loam soil (with similar SOC content and soil type as this study) in a study in Nebraska, while, in a Midwestern case study, a slightly increased $\mathrm{N}_{2} \mathrm{O}$ scenario was observed $[45,63]$. Thus, the most frequently observed changing patterns found in this study-slight to moderate increase in $\mathrm{N}_{2} \mathrm{O}$ by the incorporation of no-till (Figures 5 and A1) — can be justified from the findings of these previous publications.

From the perspective of soil $\mathrm{CO}_{2}$ emissions (resulted from SOC depletion) as well as GWPs, these same management practices are responsible for inducing the altering effects $[29,40,94,104,105]$. When higher decomposition of soil organic matter (SOM) is induced by increased soil disturbance (e.g., intense tillage), higher soil respiration along with increased $\mathrm{CO}_{2}$ emission occurs [106]. Besides, increasing soil $\mathrm{C}$ by adding crop residues or manure with a low decomposition rate can be a way of re-stocking the SOC as well as reducing $\mathrm{CO}_{2}$ efflux $[106,107]$. As a result, all the management practices involving reduced tillage, manure, reduced fertilizer with manure, and residue incorporation sequestered more or less carbon (not shown in figures) and eventually contributed to reducing GWPs (Figures $\mathrm{A} 1 \mathrm{~b}$ and $5 \mathrm{i}-\mathrm{p}$ ), which was the summation of contrasting effects of $\mathrm{C}$-sequestration (reducing $\mathrm{CO}_{2}$ efflux) and $\mathrm{N}_{2} \mathrm{O}$ in $\mathrm{CO}_{2}$ equivalents $[29,63]$. Here, manure and manure plus 50\% fertilizer replacement scenarios were able to better reduce the net GWP than the no-till scenarios due to significantly higher $\mathrm{C}$-sequestration in this area (despite producing higher $\mathrm{N}_{2} \mathrm{O}$ ).

The management impacts on SOC presided over climate change impacts in many instances $[20,108,109]$. This phenomenon was also visible for GWPs, $\mathrm{N}_{2} \mathrm{O}$, and yields (mainly cotton) here (Figures 8 and 9), which indicated that the alternative managements were also capable of maintaining reasonable yields and reduced GHGs in a changing climate (mainly temperature plus $\mathrm{CO}_{2}$ change). Moreover, each of the managements showed similar impacts in plausible future climate (level 3), as discussed for present situations (level 1). Thus, this prediction study suggested that, for the projected future climatic conditions, manure, $50 \%$ fertilizer replacements, and residue incorporation would be better choices to compensate for the negative effects of climate change on crop productivity, GHGs, and soil fertility. Though there was high $\mathrm{N}_{2} \mathrm{O}$ emission from the manure-related scenarios, the added $\mathrm{C}$ helped increase the SOC by $\mathrm{C}$-sequestration, which ultimately nullified the negative impact of the increased $\mathrm{N}_{2} \mathrm{O}$ by decreasing GWP in the poorly fertile soil of Choctawhatchee Basin [63]. Again, as the alternative management scenarios (especially the scenarios with manure incorporation) caused increases in the grain yields and decreases in the GWP, they were seen to reduce the GWP $/ \mathrm{kg}$ of grain production and brought the 
optimum benefit to both the environmental (considering GHGs) as well as the economic ends (benefits from the increased yields). No doubt, this is a win-win scenario for the basin.

\subsection{Limitation and Future Scope}

As with some of the other studies, limitations included (1) the lack of GHG observed data to conduct a thorough calibration and validation of the model, which could have increased the confidence of the model predictions to a great extent [34]. The absence of observations of GHGs is a limitation of some of the studies, including this study. The effect of this limitation was reduced by the two-step validation. In the first step, we validated with county-level crop yields. This procedure was similar to earlier studies with no observations of GHGs $[20,29,35,42]$. In the second step, the DNDC simulations of $\mathrm{N}_{2} \mathrm{O}$ were compared with county-level simulations from an earlier study. (2) The study did not include a full factor design with all factors (management $\times$ temperature $\times \mathrm{CO}_{2}$ emissions $\times$ precipitation), which would result in 11,520 scenarios (eight temperature $\times$ five precipitation $\times$ three $\mathrm{CO}_{2}$ concentrations $\times$ eight managements $\times$ four crops $\times$ three outputs parameters $\left(\mathrm{N}_{2} \mathrm{O}, \mathrm{GWP}\right.$, yield)). Therefore, a future study requires more resources beyond the scope of this project. (3) Finally, the climate scenarios were generated with change factors rather than CMIP6 (Coupled Model Intercomparison Project Phase 6) simulations from regional or global circulation models. These would require more resources beyond the scope of this project and be deferred for a future study. Additionally, incorporating a multi-year cropping system with crop rotations was deferred for future work.

\section{Conclusions}

This study was an effort to assess the impact of plausible climate change scenarios on the base management practice while identifying effective GHG mitigation options at both present as well as the end of the 21st century. In addition, it presented the spatial distribution of GHGs of the Choctawhatchee Basin along with the agricultural hotspots, which provided a comprehensive visual of the basin's cropping system, hotspot, related total emissions, and emission rates associated with all the major crops under the tested scenarios. As for results, various levels of manure addition, $50 \%$ fertilizer replacement, and residue incorporation scenarios seemed to cause total NBs (in terms of GWPs) of 17.8-65.1 thousand $\mathrm{MT} \mathrm{CO}_{2}$-eq., 41.3 thousand $\mathrm{MT} \mathrm{CO}_{2}$-eq., and 33.7 thousand $\mathrm{MT} \mathrm{CO}_{2}$-eq, respectively, for the whole cropping system of the basin at the present timeline. Tillage with two types of residues caused 0.12-0.51 thousand $\mathrm{MT} \mathrm{CO}_{2}$ eq. Overall, the tested alternative managements also reacted similarly under the plausible climate change scenarios tested, though some inter-crop variabilities were visible in climate scenarios of both timelines. Thus, in the changing climate of this region, manure amendments, fertilizer replacement, and residue incorporation cases can be claimed to induce better mitigation potential of GHGs without affecting the grain yields significantly. On the other hand, the tillage scenarios did not prove to be very beneficial and were not recommended for this region.

The research presented a systematic approach of scenario generation with both climate and management in terms of three major decision outputs (grain yield, $\mathrm{N}_{2} \mathrm{O}$, and GWP per ha or $\mathrm{kg}$ yield), which were not explored much in previous studies on the DNDC model. The results can eventually help the stakeholder choose environmentally beneficial agricultural managements that can also maintain desired yields at the data-scarce region. However, the model being coarsely validated, the major scope of improvement is a thorough validation with experimental data to gain higher confidence in the results. Additionally, the use of directly projected climate data from global circulation models, full factor design including precipitation bounds in the third level, and multi-year crop rotations might have included wider and more practical observations, which can be potential future scopes to improve over the recent limitations. Another future scope of the study can be the ArcGIS-based economic model (e.g., ENVISION) integration with DNDC to conduct an agricultural life cycle analysis (LCA) or an economic analysis [29,35]. 
Supplementary Materials: The following are available online at https://www.mdpi.com/article/10 .3390 /agronomy11071323/s1, Figure S1: Impact of the 20 years spin-up time in establishing SOC equilibrium on three example grids from the regional runs, Table S1: Temperature and precipitation change in the southeastern USA by the end of the 21st century, Table S2: Temperature and precipitation change in Florida and the southeastern USA by the end of the 21st century, Table S3: Global temperature and $\mathrm{CO}_{2}$ changes under representative concentration pathways (RCPs) by the end of the 21st century; Table S4: Sources of scenarios regarding nutrient management (fertilizer, manure), residue incorporation, and reduced tillage, Table S5: The median changes of grain yields, $\mathrm{N}_{2} \mathrm{O}, \mathrm{CO}_{2}$, and GWPs rates for four major crops of the Choctawhatchee Basin.

Author Contributions: Conceptualization, M.A., G.C., A.A.; methodology, M.A.; validation, M.A., R.L.; formal analysis, M.A.; data curation, M.A., R.L.; writing-original draft preparation, M.A.; writingreview and editing, A.A., G.C., M.A., R.L.; visualization, M.A.; supervision, A.A., G.C., R.L.; funding acquisition, A.A., G.C. All authors have read and agreed to the published version of the manuscript.

Funding: This material is based upon work partially supported by the National Science Foundation under Grant No. 1735235 awarded as part of the National Science Foundation Research Traineeship, USDA-NIFA capacity building grant 2017-38821-26405, USDA-NIFA Evans-Allen Project, Grant 11979180/2016-01711, USDA-NIFA grant No. 2018-68002-27920.

Institutional Review Board Statement: Not applicable.

Informed Consent Statement: Not applicable.

Data Availability Statement: The datasets generated during and/or analyzed during the current study are not publicly available because further studies are being done on them. However, they are available from the corresponding author on reasonable request.

Conflicts of Interest: The authors declare no conflict of interest. 


\section{Appendix A}

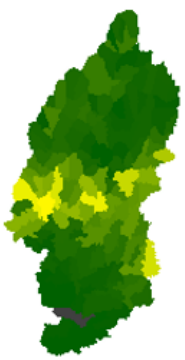

Baseline

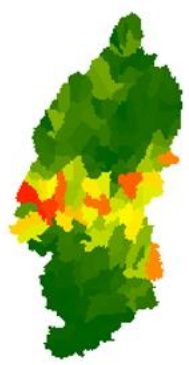

2000 kgC/ha Manure PC: $124 \%$

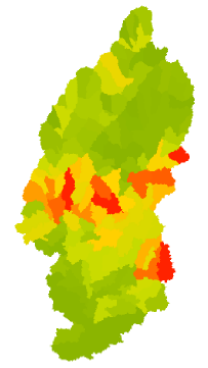

Baseline

36k tons (NB: 0)

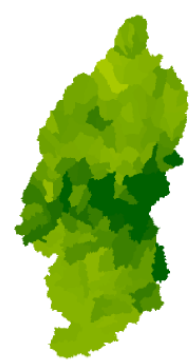

$2000 \mathrm{kgC} / \mathrm{ha}$ Manure Total: $-29 \mathrm{k}$ tons NB: $65.1 \mathrm{k}$ tons

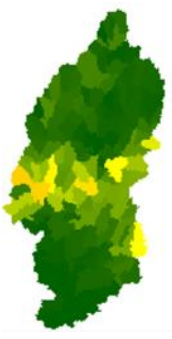

$80 \%$ Residue PC: $29 \%$

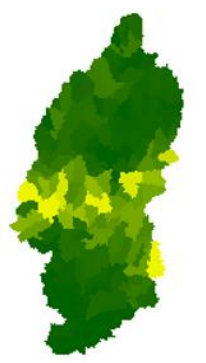

50\% Fert. +Manure PC: $21 \%$

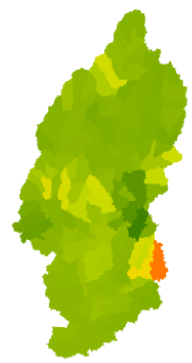

$80 \%$ Residue

Total: $0.23 \mathrm{k}$ tons NB: $33.7 \mathrm{k}$ tons

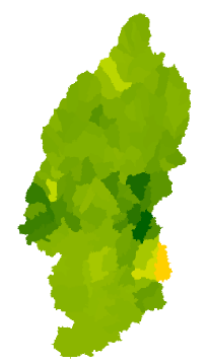

$50 \%$ fert. + Manure Total: $-0.53 \mathrm{k}$ tons NB: $41.3 \mathrm{k}$ tons

(a)

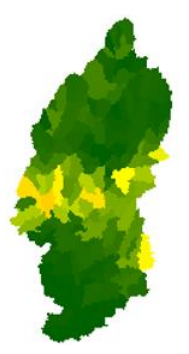

$500 \mathrm{kgC} /$ ha Manure PC: $29 \%$

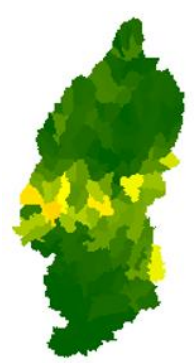

No-till-15\% residue PC: $20 \%$

(b)

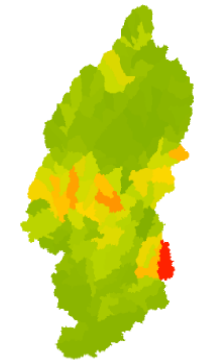

$500 \mathrm{~kg} \mathrm{C} / \mathrm{ha} \mathrm{Ma-}$ nure

Total: $18.2 \mathrm{k}$ tons NB: $17.8 \mathrm{k}$ tons

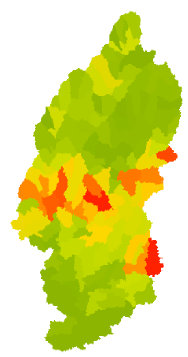

No-till-15\% residue $30.9 \mathrm{k}$ tons NB: $0.51 \mathrm{k}$ tons

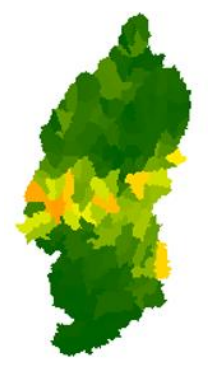

$1000 \mathrm{kgC} /$ ha Manure PC: $56 \%$

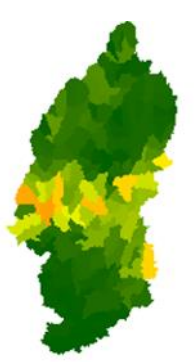

No-till-50\% residue PC: $51 \%$

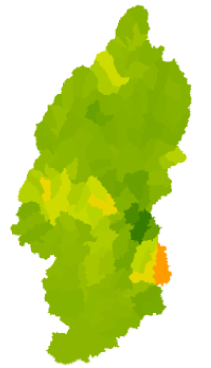

$1000 \mathrm{~kg} \mathrm{C/ha}$ Manure

Total: $0.18 \mathrm{k}$ tons NB: $34.3 \mathrm{k}$ tons

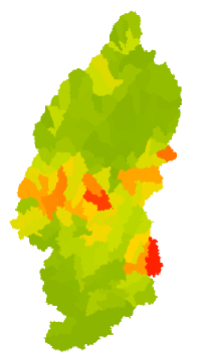

No-till-50\% residue

$23.9 \mathrm{k}$ tons

NB: $0.12 \mathrm{k}$ tons

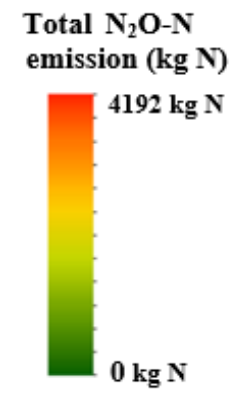

Total GWP

(kg CO 2 eq.) :

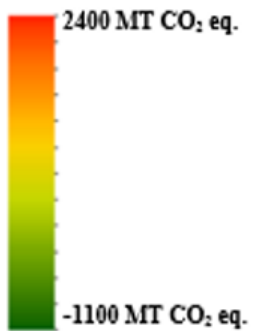

Figure A1. The (a) median total $\mathrm{N}_{2} \mathrm{O}-\mathrm{N}$ emission and the (b) median total GWP from Choctawhatchee Basin for four major cropping systems of the region (PC: percent change, NB: net benefit, MT: metric ton). The maps only present total agricultural GHGs from each HUC 12 watersheds for the tested crops. 


\section{References}

1. Ashiq, W.; Vasava, H.; Cheema, M.; Dunfield, K.; Daggupati, P.; Biswas, A. Interactive Role of Topography and Best Management Practices on N2O Emissions from Agricultural Landscape. Soil Tillage Res. 2021, 212, 105063. [CrossRef]

2. Carlson, K.M.; Gerber, J.S.; Mueller, N.D.; Herrero, M.; MacDonald, G.K.; Brauman, K.A.; Havlik, P.; O'Connell, C.S.; Johnson, J.A.; Saatchi, S.; et al. Greenhouse Gas Emissions Intensity of Global Croplands. Nat. Clim. Chang. 2017, 7, 63-68. [CrossRef]

3. Pratibha, G.; Srinivas, I.; Rao, K.V.; Raju, B.M.K.; Shanker, A.K.; Jha, A.; Uday Kumar, M.; Srinivasa Rao, K.; Sammi Reddy, K. Identification of Environment Friendly Tillage Implement as a Strategy for Energy Efficiency and Mitigation of Climate Change in Semiarid Rainfed Agro Ecosystems. J. Clean. Prod. 2019, 214, 524-535. [CrossRef]

4. Rosenzweig, C.; Tubiello, F.N. Adaptation and Mitigation Strategies in Agriculture: An Analysis of Potential Synergies. Mitig. Adapt. Strat. Glob. Chang. 2007, 12, 855-873. [CrossRef]

5. Xu, B.; Lin, B. Factors Affecting CO 2 Emissions in China's Agriculture Sector: Evidence from Geographically Weighted Regression Model. Energy Policy 2017, 104, 404-414. [CrossRef]

6. Brentrup, F.; Küsters, J.; Lammel, J.; Barraclough, P.; Kuhlmann, H. Environmental Impact Assessment of Agricultural Production Systems Using the Life Cycle Assessment (LCA) Methodology II. The Application to N Fertilizer Use in Winter Wheat Production Systems. Eur. J. Agron. 2004, 20, 265-279. [CrossRef]

7. Keairns, D.L.; Darton, R.C.; Irabien, A. The Energy-Water-Food Nexus. Annu. Rev. Chem. Biomol. Eng. 2016, 7, 239-262. [CrossRef] [PubMed]

8. Mannan, M.; Al-Ansari, T.; Mackey, H.R.; Al-Ghamdi, S.G. Quantifying the Energy, Water and Food Nexus: A Review of the Latest Developments Based on Life-Cycle Assessment. J. Clean. Prod. 2018, 193, 300-314. [CrossRef]

9. Endo, A.; Burnett, K.; Orencio, P.M.; Kumazawa, T.; Wada, C.A.; Ishii, A.; Tsurita, I.; Taniguchi, M. Methods of the Water-EnergyFood Nexus. Water 2015, 7, 5806-5830. [CrossRef]

10. Zhang, C.; Chen, X.; Li, Y.; Ding, W.; Fu, G. Water-Energy-Food Nexus: Concepts, Questions and Methodologies. J. Clean. Prod. 2018, 195, 625-639. [CrossRef]

11. Meinshausen, M.; Smith, S.J.; Calvin, K.; Daniel, J.S.; Kainuma, M.L.T.; Lamarque, J.-F.; Matsumoto, K.; Montzka, S.A.; Raper, S.C.B.; Riahi, K.; et al. The RCP Greenhouse Gas Concentrations and Their Extensions from 1765 to 2300. Clim. Chang. 2011, 109, 213. [CrossRef]

12. Myhre, G.; Shindell, D.; Bréon, F.M.; Collins, W.; Fuglestvedt, J.; Huang, J.; Koch, D.; Lamarque, J.F.; Lee, D.; Mendoza, B. Anthropogenic and Natural Radiative Forcing, Climate Change 2013: The Physical Science Basis. Contribution of Working Group I to the Fifth Assessment Report of the Intergovernmental Panel on Climate Change; Cambridge University Press: Cambridge, UK, 2013; pp. 659-740.

13. Alvarez, R. A Review of Nitrogen Fertilizer and Conservation Tillage Effects on Soil Organic Carbon Storage. Soil Use Manag. 2005, 21, 38-52. [CrossRef]

14. Fang, J.; Yu, G.; Liu, L.; Hu, S.; Chapin, F.S. Climate Change, Human Impacts, and Carbon Sequestration in China. Proc. Natl. Acad. Sci. USA 2018, 115, 4015-4020. [CrossRef]

15. Li, L.; Zheng, Z.; Wang, W.; Biederman, J.A.; Xu, X.; Ran, Q.; Qian, R.; Xu, C.; Zhang, B.; Wang, F.; et al. Terrestrial N2O Emissions and Related Functional Genes under Climate Change: A Global Meta-Analysis. Glob. Chang. Biol. 2020, 26, 931-943. [CrossRef]

16. Kang, Y.; Khan, S.; Ma, X. Climate Change Impacts on Crop Yield, Crop Water Productivity and Food Security-A Review. Prog. Nat. Sci. 2009, 19, 1665-1674. [CrossRef]

17. Raza, A.; Razzaq, A.; Mehmood, S.S.; Zou, X.; Zhang, X.; Lv, Y.; Xu, J. Impact of Climate Change on Crops Adaptation and Strategies to Tackle Its Outcome: A Review. Plants 2019, 8, 34. [CrossRef]

18. Kukal, M.S.; Irmak, S. Climate-Driven Crop Yield and Yield Variability and Climate Change Impacts on the U.S. Great Plains Agricultural Production. Sci. Rep. 2018, 8, 3450. [CrossRef] [PubMed]

19. Müller, C.; Elliott, J.; Chryssanthacopoulos, J.; Deryng, D.; Folberth, C.; Pugh, T.A.M.; Schmid, E. Implications of Climate Mitigation for Future Agricultural Production. Environ. Res. Lett. 2015, 10, 125004. [CrossRef]

20. Thomson, A.M.; Izaurralde, R.C.; Rosenberg, N.J.; He, X. Climate Change Impacts on Agriculture and Soil Carbon Sequestration Potential in the Huang-Hai Plain of China. Agric. Ecosyst. Environ. 2006, 114, 195-209. [CrossRef]

21. Kaye, J.P.; Quemada, M. Using Cover Crops to Mitigate and Adapt to Climate Change. A Review. Agron. Sustain. Dev. 2017, 37, 4. [CrossRef]

22. Climate Change 2007-Impacts, Adaptation and Vulnerability: Contribution of Working Group II to the Fourth Assessment Report of the Intergovernmental Panel on Climate Change; 1. Publ.; Parry, M.L.; IPCC (Eds.) Cambridge University Press: Cambridge, UK, 2007; ISBN 978-0-521-88010-7.

23. Giltrap, D.L.; Li, C.; Saggar, S. DNDC: A Process-Based Model of Greenhouse Gas Fluxes from Agricultural Soils. Agric. Ecosyst. Environ. 2010, 136, 292-300. [CrossRef]

24. Mangalassery, S.; Sjögersten, S.; Sparkes, D.L.; Sturrock, C.J.; Craigon, J.; Mooney, S.J. To What Extent Can Zero Tillage Lead to a Reduction in Greenhouse Gas Emissions from Temperate Soils? Sci. Rep. 2014, 4, 4586. [CrossRef] [PubMed]

25. Sainju, U.M. A Global Meta-Analysis on the Impact of Management Practices on Net Global Warming Potential and Greenhouse Gas Intensity from Cropland Soils. PLoS ONE 2016, 11, e0148527. [CrossRef] [PubMed] 
26. Sapkota, T.B.; Jat, M.L.; Aryal, J.P.; Jat, R.K.; Khatri-Chhetri, A. Climate Change Adaptation, Greenhouse Gas Mitigation and Economic Profitability of Conservation Agriculture: Some Examples from Cereal Systems of Indo-Gangetic Plains. J. Integr. Agric. 2015, 14, 1524-1533. [CrossRef]

27. Mehra, P.; Baker, J.; Sojka, R.E.; Bolan, N.; Desbiolles, J.; Kirkham, M.B.; Ross, C.; Gupta, R. Chapter Five-A Review of Tillage Practices and Their Potential to Impact the Soil Carbon Dynamics. In Advances in Agronomy; Sparks, D.L., Ed.; Academic Press: Cambridge, MA, USA, 2018; Volume 150, pp. 185-230.

28. Farahbakhshazad, N.; Dinnes, D.L.; Li, C.; Jaynes, D.B.; Salas, W. Modeling Biogeochemical Impacts of Alternative Management Practices for a Row-Crop Field in Iowa. Agric. Ecosyst. Environ. 2008, 123, 30-48. [CrossRef]

29. Tabatabaie, S.M.H.; Bolte, J.P.; Murthy, G.S. A Regional Scale Modeling Framework Combining Biogeochemical Model with Life Cycle and Economic Analysis for Integrated Assessment of Cropping Systems. Sci. Total Environ. 2018, 625, 428-439. [CrossRef] [PubMed]

30. Smith, K.A.; Thomson, P.E.; Clayton, H.; Mctaggart, I.P.; Conen, F. Effects of Temperature, Water Content and Nitrogen Fertilisation on Emissions of Nitrous Oxide by Soils. Atmos. Environ. 1998, 32, 3301-3309. [CrossRef]

31. Tongwane, M.; Mdlambuzi, T.; Moeletsi, M.; Tsubo, M.; Mliswa, V.; Grootboom, L. Greenhouse Gas Emissions from Different Crop Production and Management Practices in South Africa. Environ. Dev. 2016, 19, 23-35. [CrossRef]

32. Chen, Z.; Wang, J.; Deng, N.; Lv, C.; Wang, Q.; Yu, H.; Li, W. Modeling the Effects of Farming Management Practices on Soil Organic Carbon Stock at a County-Regional Scale. CATENA 2018, 160, 76-89. [CrossRef]

33. Jiang, G.; Zhang, W.; Xu, M.; Kuzyakov, Y.; Zhang, X.; Wang, J.; Di, J.; Murphy, D.V. Manure and Mineral Fertilizer Effects on Crop Yield and Soil Carbon Sequestration: A Meta-Analysis and Modeling across China. Glob. Biogeochem. Cycles 2018, 32, 1659-1672. [CrossRef]

34. Goglio, P.; Smith, W.N.; Grant, B.B.; Desjardins, R.L.; McConkey, B.G.; Campbell, C.A.; Nemecek, T. Accounting for Soil Carbon Changes in Agricultural Life Cycle Assessment (LCA) Review. J. Clean. Prod. 2015, 104, 23-39. [CrossRef]

35. Tabatabaie, S.M.H.; Murthy, G.S. Effect of Geographical Location and Stochastic Weather Variation on Life Cycle Assessment of Biodiesel Production from Camelina in the Northwestern USA. Int. J. Life Cycle Assess. 2017, 22, 867-882. [CrossRef]

36. Li, C. Quantifying Greenhouse Gas Emissions from Soils: Scientific Basis and Modeling Approach. Soil Sci. Plant Nutr. 2007, 53, 344-352. [CrossRef]

37. Li, C.; Frolking, S.E.; Harriss, R.C.; Terry, R.E. Modeling Nitrous Oxide Emissions from Agriculture: A Florida Case Study. Chemosphere 1994, 28, 1401-1415. [CrossRef]

38. Li, C.; Frolking, S.; Frolking, T.A. A Model of Nitrous Oxide Evolution from Soil Driven by Rainfall Events: 1 . Model Structure and Sensitivity. J. Geophys. Res. Atmos. 1992, 97, 9759-9776. [CrossRef]

39. Uzoma, K.C.; Smith, W.; Grant, B.; Desjardins, R.L.; Gao, X.; Hanis, K.; Tenuta, M.; Goglio, P.; Li, C. Assessing the Effects of Agricultural Management on Nitrous Oxide Emissions Using Flux Measurements and the DNDC Model. Agric. Ecosyst. Environ. 2015, 206, 71-83. [CrossRef]

40. Qin, F.; Zhao, Y.; Shi, X.; Xu, S.; Yu, D. Sensitivity and Uncertainty Analysis for the DeNitrification-DeComposition Model, a Case Study of Modeling Soil Organic Carbon Dynamics at a Long-Term Observation Site with a Rice-Bean Rotation. Comput. Electron. Agric. 2016, 124, 263-272. [CrossRef]

41. Goglio, P.; Smith, W.N.; Grant, B.B.; Desjardins, R.L.; Gao, X.; Hanis, K.; Tenuta, M.; Campbell, C.A.; McConkey, B.G.; Nemecek, T.; et al. A Comparison of Methods to Quantify Greenhouse Gas Emissions of Cropping Systems in LCA. J. Clean. Prod. 2018, 172, 4010-4017. [CrossRef]

42. Perlman, J.; Hijmans, R.J.; Horwath, W.R. Modelling Agricultural Nitrous Oxide Emissions for Large Regions. Environ. Model. Softw. 2013, 48, 183-192. [CrossRef]

43. CPYRWMA. Characteristics of the River Basins-Choctawhatchee, Pea and Yellow Rivers Water Management Authority. Available online: https: / / cpyrwma.alabama.gov/river-basins / (accessed on 15 June 2021).

44. USDA-NASS. USDA-National Agricultural Statistics Service-Research and Science-Cropland Data Layer Releases. Available online: https:/ / www.nass.usda.gov/Research_and_Science/Cropland/Release/index.php (accessed on 31 May 2020).

45. Franzluebbers, A.J. Soil Organic Carbon Sequestration and Agricultural Greenhouse Gas Emissions in the Southeastern USA. Soil Tillage Res. 2005, 83, 120-147. [CrossRef]

46. Arango Argoti, M.A. Nitrous Oxide Emissions: Measurements in Corn and Simulations at Field and Regional Scale. Ph.D. Thesis, Kansas State University, Manhattan, KS, USA, 2013.

47. Biswal, A. Regional Application of Process Based Biogeochemical Model DNDC in Godavari Sub-Basin. Comput. Ecol. Softw. 2016, 6, 139.

48. USDA-NRCS. Geospatial Data Gateway. Available online: https://datagateway.nrcs.usda.gov/ (accessed on 31 May 2019).

49. USDA-NRCS. Soil Data Viewer 6.2 I NRCS Soils. Available online: https://www.nrcs.usda.gov/wps/portal/nrcs/detail/soils/ survey / geo/?cid=nrcseprd337066 (accessed on 31 May 2019).

50. Butler, T.; Vermeylen, F.; Lehmann, C.M.; Likens, G.E.; Puchalski, M. Increasing Ammonia Concentration Trends in Large Regions of the USA Derived from the NADP/AMoN Network. Atmos. Environ. 2016, 146, 132-140. [CrossRef]

51. US EPA. Clean Air Status and Trends Network (CASTNET). Available online: https://www.epa.gov/castnet (accessed on 11 January 2019). 
52. Thornton, P.E.; Thornton, M.M.; Mayer, B.W.; Wilhelmi, N.; Wei, Y.; Devarakonda, R.; Cook, R.B. Daymet: Daily Surface Weather Data on a 1-Km Grid for North America; Version 2; Oak Ridge National Lab. (ORNL): Oak Ridge, TN, USA, 2014.

53. Del Grosso, S.J.; Parton, W.J.; Mosier, A.R.; Walsh, M.K.; Ojima, D.S.; Thornton, P.E. DAYCENT National-Scale Simulations of Nitrous Oxide Emissions from Cropped Soils in the United States. J. Environ. Qual. 2006, 35, 1451-1460. [CrossRef] [PubMed]

54. Anandhi, A.; Sharma, A.; Sylvester, S. Can Meta-Analysis Be Used as a Decision-Making Tool for Developing Scenarios and Causal Chains in Eco-Hydrological Systems? Case Study in Florida. Ecohydrology 2018, 11, e1997.

55. Anandhi, A.; Bentley, C. Predicted 21st Century Climate Variability in Southeastern US Using Downscaled CMIP5 and MetaAnalysis. Catena 2018, 170, 409-420. [CrossRef]

56. Cammarano, D.; Tian, D. The Effects of Projected Climate and Climate Extremes on a Winter and Summer Crop in the Southeast USA. Agric. For. Meteorol. 2018, 248, 109-118. [CrossRef]

57. Muhati, G.L.; Olago, D.; Olaka, L. Past and Projected Rainfall and Temperature Trends in a Sub-Humid Montane Forest in Northern Kenya Based on the CMIP5 Model Ensemble. Glob. Ecol. Conserv. 2018, 16, e00469. [CrossRef]

58. Toomsan, B.; McDonagh, J.F.; Limpinuntana, V.; Giller, K.E. Nitrogen Fixation by Groundnut and Soyabean and Residual Nitrogen Benefits to Rice in Farmers' Fields in Northeast Thailand. Plant Soil 1995, 175, 45-56. [CrossRef]

59. AUBURN; Soil and Forage Testing Lab. The Basis of Soil Testing. Available online: https://ssl.acesag.auburn.edu/anr/soillab/ forms / (accessed on 10 June 2019).

60. David, E.K. AESL. Available online: http:/ /aesl.ces.uga.edu/ (accessed on 10 June 2019).

61. USDA-NASS. Field Crops Usual Planting and Harvesting Dates. Available online: https://usda.library.cornell.edu/concern/ publications/vm40xr56k (accessed on 11 June 2019).

62. Baker, N.T. Tillage Practices in the Conterminous United States, 1989-2004-Datasets Aggregated by Watershed; U.S. Department of the Interior: Washington, WA, USA; US Geological Survey Reston: Reston, VA, USA, 2011.

63. Li, C. Modeling Impact of Agricultural Practices on Soil C and N2O Emissions. In Soil Management and Greenhouse Effect; Lal, R., Kimble, J., Levine, E., Eds.; CRC Press: Boca Raton, FL, USA, 1995; pp. 101-112.

64. Li, C.; Narayanan, V.; Harriss, R.C. Model Estimates of Nitrous Oxide Emissions from Agricultural Lands in the United States. Glob. Biogeochem. Cycles 1996, 10, 297-306. [CrossRef]

65. USGS. Current Conditions for Florida_Groundwater. Available online: https: / / waterdata.usgs.gov $/ \mathrm{fl} / \mathrm{nwis} / \mathrm{current} /$ ?type=gw\# Equipment_malfunction (accessed on 13 December 2020).

66. Pirttioja, N.; Carter, T.R.; Fronzek, S.; Bindi, M.; Hoffmann, H.; Palosuo, T.; Ruiz-Ramos, M.; Tao, F.; Trnka, M.; Acutis, M.; et al. Temperature and Precipitation Effects on Wheat Yield across a European Transect: A Crop Model Ensemble Analysis Using Impact Response Surfaces. Clim. Res. 2015, 65, 87-105. [CrossRef]

67. Streck, N.A. Climate Change and Agroecosystems: The Effect of Elevated Atmospheric CO2 and Temperature on Crop Growth, Development, and Yield. Ciência Rural 2005, 35, 730-740. [CrossRef]

68. Nie, T.; Zhang, Z.; Qi, Z.; Chen, P.; Sun, Z.; Liu, X. Characterizing Spatiotemporal Dynamics of CH4 Fluxes from Rice Paddies of Cold Region in Heilongjiang Province under Climate Change. Int. J. Environ. Res. Public Health 2019, 16, 692. [CrossRef]

69. Pribyl, D.W. A Critical Review of the Conventional SOC to SOM Conversion Factor. Geoderma 2010, 156, 75-83. [CrossRef]

70. Vasques, G.M.; Grunwald, S.; Harris, W.G. Spectroscopic Models of Soil Organic Carbon in Florida, U.S.A. J. Environ. Qual. 2010, 39, 923-934. [CrossRef]

71. Broch, A.; Hoekman, S.K.; Unnasch, S. A Review of Variability in Indirect Land Use Change Assessment and Modeling in Biofuel Policy. Environ. Sci. Policy 2013, 29, 147-157. [CrossRef]

72. Ukaew, S.; Beck, E.; Meki, M.N.; Shonnard, D.R. Application of the Roundtable on Sustainable Biofuels Method to Regional Differences in Nitrous Oxide Emissions for the Rapeseed Hydrotreated Renewable Jet Life Cycle. J. Clean. Prod. 2014, 83, 220-227. [CrossRef]

73. USDA-NASS, Quick Stats Lite. Available online: https://www.nass.usda.gov/Quick_Stats/Lite/index.php (accessed on 25 June 2019).

74. Keeney, D.R.; Fillery, I.R.; Marx, G.P. Effect of Temperature on the Gaseous Nitrogen Products of Denitrification in a Silt Loam Soil. Soil Sci. Soc. Am. J. 1979, 43, 1124-1128. [CrossRef]

75. Kirschbaum, M.U. Will Changes in Soil Organic Carbon Act as a Positive or Negative Feedback on Global Warming? Biogeochemistry 2000, 48, 21-51. [CrossRef]

76. Asseng, S.; Jamieson, P.D.; Kimball, B.; Pinter, P.; Sayre, K.; Bowden, J.W.; Howden, S.M. Simulated Wheat Growth Affected by Rising Temperature, Increased Water Deficit and Elevated Atmospheric CO2. Field Crop. Res. 2004, 85, 85-102. [CrossRef]

77. Eekhout, J.P.; Hunink, J.E.; Terink, W.; de Vente, J. Why Increased Extreme Precipitation under Climate Change Negatively Affects Water Security. Hydrol. Earth Syst. Sci. 2018, 22, 5935-5946. [CrossRef]

78. Deryng, D.; Conway, D.; Ramankutty, N.; Price, J.; Warren, R. Global Crop Yield Response to Extreme Heat Stress under Multiple Climate Change Futures. Environ. Res. Lett. 2014, 9, 034011. [CrossRef]

79. Beillouin, D.; Schauberger, B.; Bastos, A.; Ciais, P.; Makowski, D. Impact of Extreme Weather Conditions on European Crop Production in 2018. Philos. Trans. R. Soc. B 2020, 375, 20190510. [CrossRef]

80. Powell, J.P.; Reinhard, S. Measuring the Effects of Extreme Weather Events on Yields. Weather Clim. Extrem. 2016, 12, 69-79. [CrossRef]

81. Rowhani, P.; Lobell, D.B.; Linderman, M.; Ramankutty, N. Climate Variability and Crop Production in Tanzania. Agric. For. Meteorol. 2011, 151, 449-460. [CrossRef] 
82. Polley, H.W. Implications of Atmospheric and Climatic Change for Crop Yield and Water Use Efficiency. Crop Sci. 2002, 42, 131-140. [CrossRef] [PubMed]

83. Rötter, R.; van de Geijn, S.C. Climate Change Effects on Plant Growth, Crop Yield and Livestock. Clim. Chang. 1999, 43, 651-681. [CrossRef]

84. Ainsworth, E.A.; McGrath, J.M. Direct Effects of Rising Atmospheric Carbon Dioxide and Ozone on Crop Yields. In Climate Change and Food Security: Adapting Agriculture to a Warmer World; Lobell, D., Burke, M., Eds.; Advances in Global Change Research; Springer Netherlands: Dordrecht, The Netherlands, 2010; pp. 109-130. ISBN 978-90-481-2953-9.

85. DaMatta, F.M.; Grandis, A.; Arenque, B.C.; Buckeridge, M.S. Impacts of Climate Changes on Crop Physiology and Food Quality. Food Res. Int. 2010, 43, 1814-1823. [CrossRef]

86. Schaufler, G.; Kitzler, B.; Schindlbacher, A.; Skiba, U.; Sutton, M.A.; Zechmeister-Boltenstern, S. Greenhouse Gas Emissions from European Soils under Different Land Use: Effects of Soil Moisture and Temperature. Eur. J. Soil Sci. 2010, 61, 683-696. [CrossRef]

87. Cox, P.M.; Betts, R.A.; Jones, C.D.; Spall, S.A.; Totterdell, I.J. Acceleration of Global Warming Due to Carbon-Cycle Feedbacks in a Coupled Climate Model. Nature 2000, 408, 184-187. [CrossRef] [PubMed]

88. Ise, T.; Moorcroft, P.R. The Global-Scale Temperature and Moisture Dependencies of Soil Organic Carbon Decomposition: An Analysis Using a Mechanistic Decomposition Model. Biogeochemistry 2006, 80, 217-231. [CrossRef]

89. Butterbach-Bahl, K.; Dannenmann, M. Denitrification and Associated Soil N2O Emissions Due to Agricultural Activities in a Changing Climate. Curr. Opin. Environ. Sustain. 2011, 3, 389-395. [CrossRef]

90. Singh, B.K.; Bardgett, R.D.; Smith, P.; Reay, D.S. Microorganisms and Climate Change: Terrestrial Feedbacks and Mitigation Options. Nat. Rev. Microbiol. 2010, 8, 779-790. [CrossRef] [PubMed]

91. Gill, R.A.; Anderson, L.J.; Polley, H.W.; Johnson, H.B.; Jackson, R.B. Potential Nitrogen Constraints on Soil Carbon Sequestration Under Low and Elevated Atmospheric Co2. Ecology 2006, 87, 41-52. [CrossRef] [PubMed]

92. van Veen, J.A.; Liljeroth, E.; Lekkerkerk, L.J.A.; Van de Geijn, S.C. Carbon Fluxes in Plant-Soil Systems at Elevated Atmospheric CO2 Levels. Ecol. Appl. 1991, 1, 175-181. [CrossRef] [PubMed]

93. Chen, H. Modeling Impacts of Mulching and Climate Change on Crop Production and N2O Emission in the Loess Plateau of China. Agric. For. Meteorol. 2019, 268, 86-97. [CrossRef]

94. Chen, H.; Zhao, Y.; Feng, H.; Li, H.; Sun, B. Assessment of Climate Change Impacts on Soil Organic Carbon and Crop Yield Based on Long-Term Fertilization Applications in Loess Plateau, China. Plant Soil 2015, 390, 401-417. [CrossRef]

95. Ludwig, B.; Jäger, N.; Priesack, E.; Flessa, H. Application of the DNDC Model to Predict N2O Emissions from Sandy Arable Soils with Differing Fertilization in a Long-Term Experiment. J. Plant Nutr. Soil Sci. 2011, 174, 350-358. [CrossRef]

96. Manna, M.C.; Swarup, A.; Wanjari, R.H.; Mishra, B.; Shahi, D.K. Long-Term Fertilization, Manure and Liming Effects on Soil Organic Matter and Crop Yields. Soil Tillage Res. 2007, 94, 397-409. [CrossRef]

97. Gelfand, I.; Philip Robertson, G. A Reassessment of the Contribution of Soybean Biological Nitrogen Fixation to Reactive N in the Environment. Biogeochemistry 2015, 123, 175-184. [CrossRef]

98. Hungria, M.; Franchini, J.C.; Campo, R.J.; Crispino, C.C.; Moraes, J.Z.; Sibaldelli, R.N.R.; Mendes, I.C.; Arihara, J. Nitrogen Nutrition of Soybean in Brazil: Contributions of Biological N2 Fixation and N Fertilizer to Grain Yield. Can. J. Plant Sci. 2011. [CrossRef]

99. Hutchinson, J.J.; Grant, B.B.; Smith, W.N.; Desjardins, R.L.; Campbell, C.A.; Worth, D.E.; Vergé, X.P. Estimates of Direct Nitrous Oxide Emissions from Canadian Agroecosystems and Their Uncertainties. Can. J. Soil. Sci. 2007, 87, 141-152. [CrossRef]

100. Abdalla, M.; Wattenbach, M.; Smith, P.; Ambus, P.; Jones, M.; Williams, M. Application of the DNDC Model to Predict Emissions of N2O from Irish Agriculture. Geoderma 2009, 151, 327-337. [CrossRef]

101. Ingraham, P.A. Assessing Nitrous Oxide and Nitrate Leaching Mitigation Potential in US Corn Crop Systems Using the DNDC Model. Agric. Syst. 2019, 175, 79-87. [CrossRef]

102. Zhou, M.; Zhu, B.; Wang, S.; Zhu, X.; Vereecken, H.; Brüggemann, N. Stimulation of $\mathrm{N}_{2} \mathrm{O}$ Emission by Manure Application to Agricultural Soils May Largely Offset Carbon Benefits: A Global Meta-Analysis. Glob. Chang. Biol. 2017, 23, 4068-4083. [CrossRef]

103. Deng, Q.; Hui, D.; Wang, J.; Yu, C.-L.; Li, C.; Reddy, K.C.; Dennis, S. Assessing the Impacts of Tillage and Fertilization Management on Nitrous Oxide Emissions in a Cornfield Using the DNDC Model: Modeling $\mathrm{N}_{2} \mathrm{O}$ Emission in a Cornfield. J. Geophys. Res. Biogeosci. 2016, 121, 337-349. [CrossRef]

104. Cui, F.; Zheng, X.; Liu, C.; Wang, K.; Zhou, Z.; Deng, J. Assessing Biogeochemical Effects and Best Management Practice for a Wheat-Maize Cropping System Using the DNDC Model. Biogeosciences 2014, 11, 91-107. [CrossRef]

105. Jiang, R.; He, W.; Zhou, W.; Hou, Y.; Yang, J.Y.; He, P. Exploring Management Strategies to Improve Maize Yield and Nitrogen Use Efficiency in Northeast China Using the DNDC and DSSAT Models. Comput. Electron. Agric. 2019, 166, 104988. [CrossRef]

106. Paustian, K.; Six, J.; Elliott, E.T.; Hunt, H.W. Management Options for Reducing CO2 Emissions from Agricultural Soils. Biogeochemistry 2000, 48, 147-163. [CrossRef]

107. Hassan, W.; David, J.; Abbas, F. Effect of Type and Quality of Two Contrasting Plant Residues on CO2 Emission Potential of Ultisol Soil: Implications for Indirect Influence of Temperature and Moisture. Catena 2014, 114, 90-96. [CrossRef]

108. Powlson, D.S.; Stirling, C.M.; Jat, M.L.; Gerard, B.G.; Palm, C.A.; Sanchez, P.A.; Cassman, K.G. Limited Potential of No-till Agriculture for Climate Change Mitigation. Nat. Clim. Chang. 2014, 4, 678-683. [CrossRef]

109. Scialabba, N.E.-H.; Müller-Lindenlauf, M. Organic Agriculture and Climate Change. Renew. Agric. Food Syst. 2010, 25, 158-169. [CrossRef] 